\title{
Ultra-violet absorption cross sections of isotopically substituted nitrous oxide species: ${ }^{14} \mathbf{N}^{14} \mathrm{NO},{ }^{15} \mathrm{~N}^{14} \mathrm{NO},{ }^{14} \mathbf{N}^{15} \mathrm{NO}$ and ${ }^{15} \mathbf{N}^{15} \mathrm{NO}$
}

\author{
P. von Hessberg ${ }^{1}$, J. Kaiser ${ }^{2,}{ }^{*}$, M. B. Enghoff ${ }^{1}$, C. A. McLinden ${ }^{3}$, S. L. Sorensen ${ }^{4}$, T. Röckmann ${ }^{2}$, and M. S. Johnson ${ }^{1}$ \\ ${ }^{1}$ Department of Chemistry, University of Copenhagen, Copenhagen, Denmark \\ ${ }^{2}$ Max-Planck Institute for Nuclear Physics, Atmospheric Physics Division, Heidelberg, Germany \\ ${ }^{3}$ Air Quality Research Branch, Meteorological Service of Canada, Toronto, Ontario, Canada \\ ${ }^{4}$ Synchrotron Radiation Research, Lund University, Lund, Sweden \\ *now at Department of Geosciences, Princeton University, Princeton, New Jersey, USA
}

Received: 23 January 2004 - Published in Atmos. Chem. Phys. Discuss.: 5 May 2004

Revised: 16 July 2004 - Accepted: 16 July 2004 - Published: 10 August 2004

\begin{abstract}
The isotopically substituted nitrous oxide species ${ }^{14} \mathrm{~N}^{14} \mathrm{NO},{ }^{15} \mathrm{~N}^{14} \mathrm{NO},{ }^{14} \mathrm{~N}^{15} \mathrm{NO}$ and ${ }^{15} \mathrm{~N}^{15} \mathrm{NO}$ were investigated by ultra-violet (UV) absorption spectroscopy. High precision cross sections were obtained for the wavelength range 181 to $218 \mathrm{~nm}$ at temperatures of 233 and $283 \mathrm{~K}$. These data are used to calculate photolytic isotopic fractionation constants as a function of wavelength. The fractionation constants were used in a three-dimensional chemical transport model in order to simulate the actual fractionation of $\mathrm{N}_{2} \mathrm{O}$ in the stratosphere, and the results were found to be in good agreement with field studies.
\end{abstract}

\section{Introduction}

Nitrous oxide is a greenhouse gas (Yung et al., 1976) and the main source of ozone depleting stratospheric $\mathrm{NO}_{\mathrm{x}}$ (Crutzen, 1970). Through the last decades there has been an interest in the isotopic composition of atmospheric nitrous oxide. Sources of atmospheric $\mathrm{N}_{2} \mathrm{O}$ are mainly microbial nitrogen conversion processes in soils and oceans (Houghton et al., 2001) which generally produce isotopically light $\mathrm{N}_{2} \mathrm{O}$ compared to atmospheric samples. The $\mathrm{N}_{2} \mathrm{O}$ emissions are balanced by the downflux of isotopically heavy $\mathrm{N}_{2} \mathrm{O}$ from the stratosphere (Kim and Craig, 1993; Yoshida and Matsuo, 1983).

The isotopic enrichment of $\mathrm{N}_{2} \mathrm{O}$ in the stratosphere is caused by its sink reactions: Stratospheric photolysis is the main sink of atmospheric $\mathrm{N}_{2} \mathrm{O}$ and the reaction with $\mathrm{O}\left({ }^{1} \mathrm{D}\right)$ also plays a role:

$\mathrm{N}_{2} \mathrm{O}+\mathrm{h} v \rightarrow \mathrm{N}_{2}+\mathrm{O}\left({ }^{1} \mathrm{D}\right)(90 \%)$

$\mathrm{N}_{2} \mathrm{O}+\mathrm{O}\left({ }^{1} \mathrm{D}\right) \rightarrow 2 \mathrm{NO}(6 \%)$

Correspondence to: M. S. Johnson

(msj@kiku.dk)
$\mathrm{N}_{2} \mathrm{O}+\mathrm{O}\left({ }^{1} \mathrm{D}\right) \rightarrow \mathrm{N}_{2}+\mathrm{O}_{2}(4 \%)$

Isotopic fractionation due to photolysis is quantified by the fractionation constant $\varepsilon$ :

$\varepsilon(\lambda)=\frac{J_{\text {heavy }}}{J_{\text {light }}}-1=\frac{I(\lambda) \sigma_{\text {heavy }}(\lambda)}{I(\lambda) \sigma_{\text {light }}(\lambda)}-1=\frac{\sigma_{\text {heavy }}(\lambda)}{\sigma_{\text {light }}(\lambda)}-1$,

where $J$ are photolysis rates of the different isotopic species, $\sigma$ are isotope specific absorption cross sections and $I$ is the actinic flux. We employ the definition of most studies in the field of atmospheric $\mathrm{N}_{2} \mathrm{O}$ isotope measurements. The quantum yield for photodissociation (1) is unity (DeMore et al., 1997).

Initial measurements of isotopic fractionation in $\mathrm{N}_{2} \mathrm{O}$ photolysis showed an isotopic enrichment in the residual $\mathrm{N}_{2} \mathrm{O}$ (Yoshida et al., 1990), but experiments at $185 \mathrm{~nm}$ (close to the UV absorption maximum) indicated near zero enrichments (Johnston et al., 1995). Therefore several authors suggested that non-standard atmospheric chemistry was responsible for generating isotopically enriched $\mathrm{N}_{2} \mathrm{O}$ (McElroy and Jones, 1996; Prasad, 1997; Zipf and Prasad, 1998).

In 1997, Yung and Miller presented a model that used the difference in vibrational zero point energy of isotopically substituted molecules in order to explain shifts in their absorption spectrum and consequently, $\varepsilon(\lambda)$. This model approximates the UV absorption spectra of isotopically heavy $\mathrm{N}_{2} \mathrm{O}$ by simply blue shifting the spectrum of ${ }^{14} \mathrm{~N}^{14} \mathrm{~N}^{16} \mathrm{O}$ by an amount corresponding to the difference in zero point energy, implying near zero isotopic fractionation at the absorption maximum at $182 \mathrm{~nm}$ (Yung and Miller, 1997). This model predicted enrichments of isotopically heavy species of $\mathrm{N}_{2} \mathrm{O}$ half as large as found by laboratory experiments (Rahn et al., 1998).

A flurry of field studies (Griffith et al., 2000; Rahn and Wahlen, 1997; Röckmann et al., 2001; Toyoda et al., 2001b; Yoshida and Toyoda, 2000) and laboratory experiments (Kaiser et al., 2002b, 2003c; Rahn et al., 1998; 
Table 1. The components of the experimental system.

\begin{tabular}{|c|c|c|}
\hline & $\begin{array}{l}\text { Experimental system (parts used } \\
\text { in Lund (A) or at both locations) }\end{array}$ & $\begin{array}{l}\text { Copenhagen system (B) } \\
\text { (if different from Lund system) }\end{array}$ \\
\hline $\begin{array}{l}\text { Light source } \\
\text { (max. energy: } 550 \mathrm{MeV} \text {, max. current: } \\
300 \mathrm{~mA} \text {, typical beam lifetime: } 3 \mathrm{~h} \text { ) }\end{array}$ & $\begin{array}{l}\text { Electron storage ring: MAX I, Lund, Sweden } \\
\text { noise rating: } 0.005 \% \\
\text { power supply: Optronic Laboratories model } 45 \text { D }\end{array}$ & Deuterium lamp Heraeus DX 222/05 TJ, \\
\hline $\begin{array}{l}\text { Monochromator beamline } 52 \\
\text { (Sorensen et al., 1990) }\end{array}$ & $1 \mathrm{~m}$ normal incidence vacuum at & $1 \mathrm{~m} \mathrm{McPherson} \mathrm{2601,} 1200$ line/mm grating \\
\hline Lenses & & $\begin{array}{l}\text { 1) fused silica bi convex } \mathrm{f}=40 \mathrm{~mm} \text {; } \\
\text { 2) fused silica plano convex } \mathrm{f}=40 \mathrm{~mm}\end{array}$ \\
\hline $\begin{array}{l}\mathrm{N}_{2} \text { flushed box containing mirrors, } \\
\text { aperture, chopper, beam splitters, } \\
\text { beam shutters and the detector }\end{array}$ & $\begin{array}{l}\text { housing of a McPherson } \\
\text { model } 2035 \text { monochromator }\end{array}$ & \\
\hline Mirrors & CVI Laser, VUVA-PM-1025-UV & \\
\hline Beam splitter/beam combiner & Acton Research, VUV BS 45-MF-1D & \\
\hline Chopper & $\begin{array}{l}\text { Thorlabs, MC } 1000 \text { employing a } 10 \\
\text { slit blade operated at } 1000 \mathrm{~Hz}\end{array}$ & \\
\hline Shutters & Vincent Associates, VS25 & \\
\hline $\begin{array}{l}\text { Signal generator controlling } \\
\text { the shutters }\end{array}$ & $\begin{array}{l}\text { Stanford Research Systems } \\
\text { digital delay generator, DG535 }\end{array}$ & \\
\hline Sample cell & $\begin{array}{l}\text { temperature controlled double wall } \\
\text { quartz cell, length of light path: } 100.0 \mathrm{~mm} \text {, } \\
\text { fused silica windows, Vogelsberger Quarzglastechnik }\end{array}$ & \\
\hline Temperature controller & Neslab ULT-80 recirculating chiller with ethanol & \\
\hline Detector & $\begin{array}{l}\text { solar blind photomultiplier tube (PMT) from } \\
\text { Electron Tubes, } 9405 \mathrm{~B}(\lambda \text { range: } 110 \mathrm{~nm}-310 \mathrm{~nm})\end{array}$ & \\
\hline PMT power supply & Stanford Research Systems, PS 325 & \\
\hline Lock-in amplifier & $\begin{array}{l}\text { Princeton Applied Research , } 5209 \text { (settings: } 12 \mathrm{~dB} \text { / } \\
\text { octave filters and a time constant of } 300 \mathrm{~ms} \text {; the full } \\
\text { scale sensitivity used was in the range: } 10-100 \mathrm{mV} \text {, } \\
\text { the shunt resistor: } 1 \mathrm{M} \Omega \text { ) }\end{array}$ & $\begin{array}{l}\text { Stanford Research Systems, SR } 850 \\
\text { (employed settings: time constant: } 300 \mathrm{~ms} \text {, } \\
18 \mathrm{~dB} \text { /octave filters, shunt resistor } 1.5 \mathrm{M} \Omega \text {, } \\
\text { sensitivity: } 0.5-50 \mathrm{mV} \text { ) }\end{array}$ \\
\hline $\mathrm{A} / \mathrm{D}$ converter & $\begin{array}{l}\text { National Instruments, PCI 6023E (12 bit) acquiring } \\
\text { data at a rate of } 1000 \mathrm{~Hz} \text {. }\end{array}$ & $\begin{array}{l}\text { internal } 18 \text { bit } \mathrm{A} / \mathrm{D} \text { converter in lock-in } \\
\text { amplifier - data transfer to PC via serial port }\end{array}$ \\
\hline Software & Data collection software written using Matlab & $\begin{array}{l}\text { Data collection and experimental control } \\
\text { software written using Matlab }\end{array}$ \\
\hline Gas handling system & $\begin{array}{l}6 \mathrm{~mm} \text { stainless steel and copper tubing with } \\
\text { Swagelok and UltraTorr fittings and Whitey shutoff } \\
\text { valves } \\
3 \text { pressure gauges }(0-13 \mathrm{hPa}, 0-130 \mathrm{hPa}, 0-1300 \mathrm{hPa}) \\
\text { Edwards } 600 \mathrm{AB} \text { Barocell capacitance manometer, } \\
0.15 \% \text { accuracy }\end{array}$ & \\
\hline Vacuum & rotary vane pump backing Varian VD-70 turbopump & \\
\hline
\end{tabular}

Röckmann et al., 2000, 2001; Toyoda et al., 2001a; Turatti et al., 2000; Umemoto, 1999; Zhang et al., 2000) have been carried out to investigate the isotopic composition of $\mathrm{N}_{2} \mathrm{O}$ in the atmosphere and to determine the effect of stratospheric photolysis on the isotopic composition. Also, new theoretical models of the absorption cross section and the resulting isotopic fractionation constants have been presented (Blake et al., 2003; Johnson et al., 2001; Morgan et al., 2004; Nanbu and Johnson, 2004).
Laboratory data and theoretical models of the isotopomer and isotopologue fractionation constants have been used as input for atmospheric models in an effort to refine our knowledge of the emissions and chemical sources and sinks of this greenhouse gas (Kaiser, 2002; Kaiser et al., 2001; McLinden et al., 2003; Morgan et al., 2004).

The most extensive information on the effects of stratospheric photolysis of $\mathrm{N}_{2} \mathrm{O}$ can be gathered by combining accurate high resolution UV absorption data with the solar 
irradiance spectrum in the relevant regions of the stratosphere. A chemistry and transport model (see Sect. 4) shows that over $99 \%$ of the stratospheric $\mathrm{N}_{2} \mathrm{O}$ photolysis takes place within the wavelength range $181-218 \mathrm{~nm}$. Knowledge of the photolytic fractionation combined with an understanding of atmospheric transport and mixing can lead to realistic models of the actual isotopic distributions.

The UV absorption spectra of the main isotopologues of ${ }^{14} \mathrm{~N}^{14} \mathrm{NO}$ are yet to be fully investigated. Selwyn and Johnston (1981) published data on ${ }^{14} \mathrm{~N}^{14} \mathrm{NO},{ }^{15} \mathrm{~N}^{14} \mathrm{NO},{ }^{14} \mathrm{~N}^{15} \mathrm{NO}$ and ${ }^{15} \mathrm{~N}^{15} \mathrm{NO}$ in the wavelength region $173-197 \mathrm{~nm}$. As the wavelength region 200 to $210 \mathrm{~nm}$ is the most important in terms of stratospheric photolysis of nitrous oxide (Yung and Miller, 1997), the data from Selwyn and Johnston are insufficient. Since the red shoulder of the $\mathrm{N}_{2} \mathrm{O}$ absorption spectrum above about $188 \mathrm{~nm}$ has very little vibrational structure (Yoshino et al., 1997), broadband photolysis and subsequent isotopic analysis appears to be a reasonable way of characterizing the magnitude of isotopic fractionation (Kaiser et al., 2002b, 2003c; Röckmann et al., 2001). Kaiser et al. (2003c) used the collective results from broadband photolysis and "single wavelength" photolysis experiments to derive a linear fit of fractionation constant vs. wavelength for the range 190 to $220 \mathrm{~nm}$.

We undertook the present study to extend the work of Selwyn and Johnston to stratospherically relevant wavelengths, to obtain more detailed information than is available from broadband or single wavelength photolysis studies and to validate the existing data. A secondary purpose is to help refine theoretical models of the effect of isotopic substitution on absorption cross sections (Blake et al., 2003; Johnson et al., 2001; Morgan et al., 2004; Nanbu and Johnson, 2004). We report the absorption spectra of ${ }^{14} \mathrm{~N}^{14} \mathrm{NO}$, ${ }^{14} \mathrm{~N}^{15} \mathrm{NO},{ }^{15} \mathrm{~N}^{14} \mathrm{NO}$ and ${ }^{15} \mathrm{~N}^{15} \mathrm{NO}$ at 233 and $283 \mathrm{~K}$ over the wavelength range 181 to $218 \mathrm{~nm}$.

\section{Experimental}

\subsection{Spectrometer}

The main requirement for the experimental setup was high precision of the resulting cross sections in order to be able to determine fractionation constants in the \%o range. In order to meet this requirement a custom-designed double beam/single detector setup was used.

The experiments were carried out at two locations:

1. One set of measurements at MAX-lab in Lund, Sweden using synchrotron radiation together with a $1 \mathrm{~m}$ vacuum monochromator.

2. A second set of measurements at the Department of Chemistry at the University of Copenhagen using a deuterium continuum lamp as light source and a UV/VIS

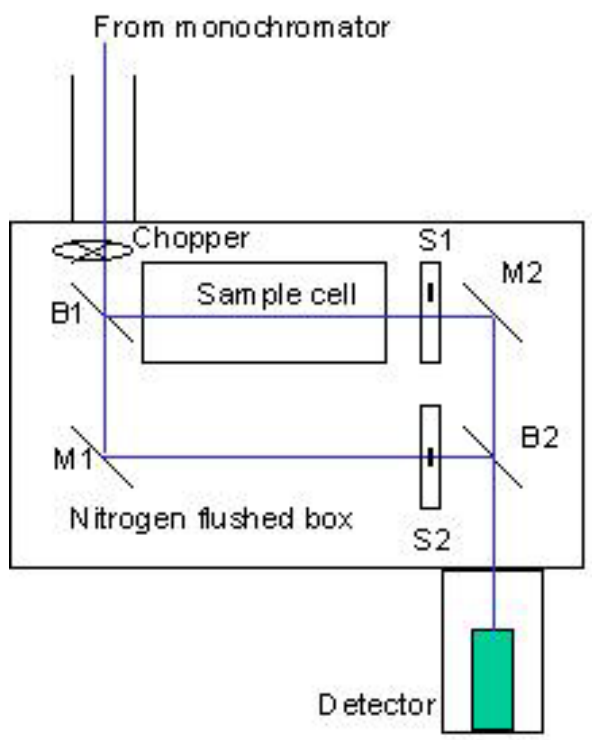

Fig. 1. Outline of the spectrometer design (B1 and B2: semi transparent mirrors (beamsplitters), M1 and M2: mirrors, S1 and S2: shutters switching between sample and reference light paths).

monochromator $(1 \mathrm{~m})$. The double beam compartment was the same in both systems.

The elements of the experimental setup are shown and described in Fig. 1 and Table 1.

\subsubsection{Temperature controlled sample cell}

The sample cell was a special double-walled design with a path length of $100 \mathrm{~mm}$. Both front and rear windows (quartz) were double with an evacuated spacing in between to provide thermal insulation. The cell was surrounded by $12 \mathrm{~mm}$ of insulating foam.

Ethanol was used as cooling liquid and was flushed through the outer jacket of the insulated sample cell. The temperature was monitored via thermistors located at the exit tube for ethanol from the double beam compartment and at the cooling unit. Later (at site B) the temperature monitoring was improved by increasing the ethanol flow and inserting a thermistor in the ethanol directly after the exit from the sample cell. The cooling unit was a Neslab ULT- 80 cryogenic cooler. It was able to stabilize the temperature to $+/-0.1 \mathrm{~K}$ over a range of $193 \mathrm{~K}$ to $283 \mathrm{~K}$. The recirculating cooling unit was connected to the sample cell via 2 insulated hoses of about $1.5 \mathrm{~m}$ length and $10 \mathrm{~mm}$ inner diameter.

At site A the temperature of the sample could only be determined with some uncertainty: $+/-0.5 \mathrm{~K}$ for the ' $283 \mathrm{~K}$ ' measurements and $+/-2.5 \mathrm{~K}$ for the ' $233 \mathrm{~K}$ ' measurements. With the improved design at site $\mathrm{B}$ the temperature was determined with an uncertainty of $+/-0.3 \mathrm{~K}$. 


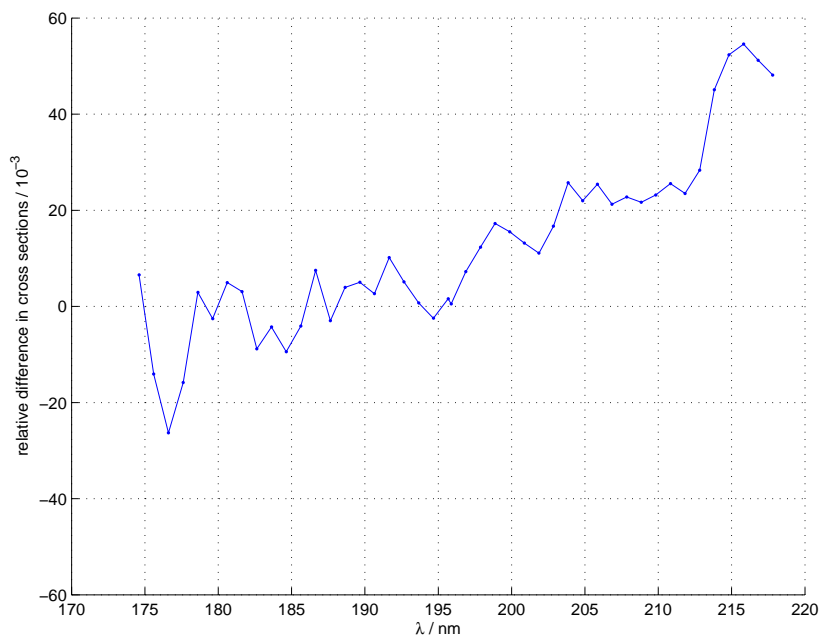

Fig. 2. Comparison of measured absolute cross sections ( $T=283 \mathrm{~K}$ ) of natural abundance nitrous oxide with literature values (Yoshino et al., 1984). The literature cross sections were measured at room temperature and have been temperature corrected following (Selwyn et al., 1977). The literature values are high resolution, averages have been calculated employing a Gaussian filter with width $0.6 \mathrm{~nm}$.

\subsubsection{Gases}

The gases used were:

- Natural abundance $\mathrm{N}_{2} \mathrm{O}, 99 \%$ (manufacturer specified) chemical purity, Sigma Aldrich, cat. no.: 29559-0, $99.3 \%$ isotopic purity ${ }^{14} \mathrm{~N}^{14} \mathrm{NO}$ (this work)

$-{ }^{15} \mathrm{~N}^{15} \mathrm{NO}$ ICON $99.50 \%$ isotopic purity

- ${ }^{14} \mathrm{~N}^{15} \mathrm{NO}$ ICON $98.95 \%$ isotopic purity

$-{ }^{15} \mathrm{~N}^{14} \mathrm{NO}$ ICON $99.22 \%$ isotopic purity

The isotopic composition of the enriched samples was checked using isotope ratio mass spectrometry and Fourier transform infrared spectroscopy (FTIR). The quoted purities reflect these measurements. The small isotopic impurities are unimportant; for example: $1 \%$ isotopic impurity of isotopically different $\mathrm{N}_{2} \mathrm{O}$ with an $\sigma(\lambda)$ differing by as much as $100 \%$ (from the main species in the sample) would lead to an error in $\varepsilon$ of only $1 \%$. While the symbol ' $\mathrm{O}$ ' is used throughout this paper for oxygen (denoting a mixture of ${ }^{16} \mathrm{O},{ }^{17} \mathrm{O}$ and ${ }^{18} \mathrm{O}$ ), it is important to note that the samples, containing less than a few per mil of the heavy isotopes, are essentially ${ }^{16} \mathrm{O}$.

Before measurements the enriched samples underwent two freeze/pump/thaw cycles (using liquid $\mathrm{N}_{2}$ ) in order to remove non-condensable gases. After finishing the experiments FTIR spectra of all the $\mathrm{N}_{2} \mathrm{O}$ samples were obtained in order to check for impurities. All observed bands in the investigated infrared region $\left(1500 \mathrm{~cm}^{-1}-4000 \mathrm{~cm}^{-1}\right)$ could be attributed to $\mathrm{N}_{2} \mathrm{O}, \mathrm{H}_{2} \mathrm{O}$ or $\mathrm{CO}_{2}$. The water concentration was found to be $<1 \%$ and the $\mathrm{CO}_{2}$ concentration was $<0.5 \%$ of the total. The $\mathrm{CO}_{2}$ and water content were estimated employing the HITRAN line parameters (Rothman et al., 2003) and the spectral fitting software NLM4 from David Griffith (Feilberg et al., 2002).

Nitrogen (99.998\% purity) was used to flush the $30 \mathrm{~L}$ double beam compartment at a flow rate of $\sim 10 \mathrm{~L} / \mathrm{min}$.

\subsection{Experimental procedure}

\subsubsection{Procedure at MAX-lab}

The $1 \mathrm{~m}$ normal incidence monochromator was used with a 1200 line/mm spherical grating. The slit width was set to $400 \mu \mathrm{m}$; this resulted in an effective photon bandwidth of about $0.7 \mathrm{~nm}$.

The double beam setup comprising a beam splitter, a beam combiner and two mirrors with the thermostatic sample cell in the sample channel (see Fig. 1) was aligned using the zero order light from the bending magnet source; the visible spot was quite well defined which made alignment by sight straightforward. The goal of the alignment was to combine the split beam into a parallel single beam in order to have light from the same region of the source beam hitting the same spot on the detector no matter which path it may have followed. In this way we minimized the influence of any possible spatial variations in detector sensitivity.

The double beam compartment containing the sample cell and detector was connected to the evacuated beam line exit port through a sapphire window. The box itself was not evacuated but flushed with $\mathrm{N}_{2}$ in order to avoid $\mathrm{UV}$ absorption by $\mathrm{O}_{2}$ and $\mathrm{H}_{2} \mathrm{O}$.

An optical chopper was mounted before the beam splitter and operated at $1000 \mathrm{~Hz}$. It was required in order to remove DC offset from for example detector dark current. The signal from the PMT was demodulated by a lock-in amplifier that generated a DC voltage proportional to the AC part of the incoming signal. The DC voltage was fed into a 12-bit A/D converter and recorded by a computer.

The grating was moved in discrete wavelength steps and was stationary during measurement of the ratio of light intensity between the sample and reference light paths. At each step the sample light was measured for four seconds after which the shutters switched the light path to the reference channel, and four seconds of reference signal were recorded.

The natural abundance $\mathrm{N}_{2} \mathrm{O}$ was taken directly from the lecture bottle. The enriched samples were stored in glass flasks and recollected after every spectrum. In order to reduce water entry into the measurement cell, the sample containers were kept below $273 \mathrm{~K}$ while filling the cell. For testing purposes spectra with different pressures of nitrous oxide were collected (at $p \approx 20 \mathrm{hPa}$ and $\mathrm{p} \approx 40 \mathrm{hPa}$ ). The higher pressures resulted in better performance since precise cross 
sections could be obtained over a broader spectral range. The final measurements were carried out at $\mathrm{p} \approx 40 \mathrm{hPa}$.

A wavelength calibration was carried out after the $\mathrm{N}_{2} \mathrm{O}$ experiments employing a linear fit on the basis of oxygen absorption lines in the Schumann- Runge band at $\sim 180 \mathrm{~nm}$, and the zero order light. After the calibration (which resulted in a wavelength shift of: $\lambda_{\text {estimated }}=1.0034 * \lambda_{\text {reading }}$ ) a comparison of the natural abundance spectrum with the temperature-corrected high-resolution data from Yoshino et al. (1997) showed a good match (Fig. 2). The temperature correction was performed using the parameterisation of Selwyn et al. (1977).

Spectra of the four gases (natural abundance, ${ }^{15} \mathrm{~N}^{15} \mathrm{NO}$, ${ }^{14} \mathrm{~N}^{15} \mathrm{NO}$ and ${ }^{15} \mathrm{~N}^{14} \mathrm{NO}$ ) were measured at 233 and $283 \mathrm{~K}$. Reference spectra of the empty sample cell were recorded before and after every sample spectrum. The $233 \mathrm{~K}$ spectra were recorded with a step size of about $2 \mathrm{~nm}$, whereas the $283 \mathrm{~K}$ spectra were recorded with a step size of about $1 \mathrm{~nm}$. The spectral region investigated was 166 to $230 \mathrm{~nm}$. However, highly accurate cross sections could only be obtained for the wavelength range of ca. $181 \mathrm{~nm}$ to about $200 \mathrm{~nm}$ due to small impurities of water in the isotopically rare samples that absorbed strongly at shorter wavelengths, and prohibitively small absorbances at longer wavelengths.

While making measurements at MAX-lab during daytime, the reproducibility was significantly worse compared to night time measurements. The data presented here are solely based on night time measurements. A simple test using liquid $\mathrm{N}_{2}$ to cool the detector housing suggested that elevated daytime detector temperatures were at least partly responsible for this.

\subsubsection{Procedure in Copenhagen}

Overall the experimental setup and procedure were largely the same as those employed at MAX-lab. The spectrometer room in Copenhagen was thermostatically stabilized to 295(+/-1)K using a mobile air conditioner. Before measuring spectra the monochromator was calibrated using lines from an $\mathrm{Hg}$ discharge lamp. The alignment procedure for the double beam setup was similar to the one outlined above with the exception that a HeNe laser was the alignment light source. The data acquisition was slightly altered: A different lock-in amplifier was used allowing acquisition of the signal in digital form directly from the amplifier. The light source was an ultra stable deuterium lamp. The short-term drift and noise of the complete system (light source, detector and amplifier) was found to be $<0.2 \%$ (within $>1 \mathrm{~min}$ ). Convex lenses of fused silica were mounted between lamp and monochromator as well as between monochromator and double beam compartment in order to get a strong collimated beam through the double beam setup. The Copenhagen data was collected using a one meter monochromator (McPherson model 2061, 1200 groove/mm grating) with a range extending to $185 \mathrm{~nm}$. The instrument did not support nitrogen flushing. The changing oxygen concentration and absorption made cross section measurements below $195 \mathrm{~nm}$ imprecise.

In Copenhagen spectra were recorded at $233 \mathrm{~K}$ and $283 \mathrm{~K}$ at $\mathrm{N}_{2} \mathrm{O}$ pressures of ca. $95 \mathrm{hPa}$. The slit widths of the monochromator were set to $800 \mu \mathrm{m}$ and the effective instrumental bandwidth (tested using an $\mathrm{Hg}$ line at $254 \mathrm{~nm}$ ) was $1.10 \mathrm{~nm}$. Four spectra were taken for every one of the four gas samples at both temperatures. The spectral range covered was $196-218 \mathrm{~nm}$. The step width was $1 \mathrm{~nm}$.

\section{Results}

\subsection{Cross sections and fractionation constants}

Fractionation constants for the isotopically rare species $\left({ }^{14} \mathrm{~N}^{15} \mathrm{NO},{ }^{15} \mathrm{~N}^{14} \mathrm{NO}\right.$ and $\left.{ }^{15} \mathrm{~N}^{15} \mathrm{NO}\right)$ were calculated from their cross sections relative to the natural abundance sample cross sections (which is regarded as ${ }^{14} \mathrm{~N}^{14} \mathrm{NO}$ ). Cross sections were calculated from three consecutive spectra: empty cell/filled cell/empty cell. The average of the two empty cell spectra was employed to quantify the background absorbance. The final results constitute an average of 3 or 4 independent sets of spectra.

In general the cross sections obtained with setup (B) displayed a better reproducibility than the Lund data (A). However the Copenhagen experiments (B) were hampered by $\mathrm{O}_{2}$ in the light path. It was therefore decided to combine the Lund (A) and Copenhagen (B) results into a single data set: The data for wavelengths shorter than $196.8 \mathrm{~nm}$ were taken from the Lund measurements (A) and the Copenhagen measurements (B) are used for the longer wavelengths. For all species and temperatures the $\varepsilon$ values derived from the Lund and Copenhagen measurements coincide within the mutual experimental errors.

The fractionation constants are presented in Figs. 3 and 4 and Tables 2 and 3. The tables also show the measured absolute cross sections; in Fig. 2 the measured absolute cross section for natural abundance is compared with the dataset from Yoshino et al. (1984).

\subsection{Uncertainties}

Measurements of high precision absolute cross sections require a number of parameters to be measured with great accuracy: path-length, pressure of the investigated species, sample temperature and absorbance. Accordingly typically quoted uncertainties for absolute cross sections are in the range of 2-4\% (Merienne et al., 1990; Selwyn and Johnston, 1981; Yoshino et al., 1984). Fractionation constants presented here are based on relative cross sections, therefore some sources of error are minimized. The main sources of errors are quantified in the following sections. 
Table 2. Cross sections and fractionation constants at $283 \mathrm{~K}$.

\begin{tabular}{|c|c|c|c|c|c|c|c|c|c|c|}
\hline \multicolumn{2}{|c|}{${ }^{14} \mathrm{~N}^{14} \mathrm{NO}$} & \multicolumn{3}{|c|}{${ }^{14} \mathrm{~N}^{15} \mathrm{NO}$} & \multicolumn{3}{|c|}{${ }^{15} \mathrm{~N}^{14} \mathrm{NO}$} & \multicolumn{3}{|c|}{${ }^{15} \mathrm{~N}^{15} \mathrm{NO}$} \\
\hline $\begin{array}{c}\text { central } \lambda / \\
\mathrm{nm}\end{array}$ & $\begin{array}{c}\sigma / 10^{-19} \\
\mathrm{~cm}^{2}\end{array}$ & $\begin{array}{c}\sigma / 10^{-19} \\
\mathrm{~cm}^{2}\end{array}$ & $\varepsilon / \%$ & $\begin{array}{c}\text { Error }\left(95 \% \mathrm{CI}^{\mathrm{a}}\right) \text { : } \\
\Delta \varepsilon / \%\end{array}$ & $\begin{array}{c}\sigma / 10^{-19} \\
\mathrm{~cm}^{2}\end{array}$ & $\varepsilon / \% 0$ & $\begin{array}{c}\text { Error }\left(95 \% \mathrm{CI}^{\mathrm{a}}\right): \\
\Delta \varepsilon / \% \%\end{array}$ & $\begin{array}{c}\sigma / 10^{-19} \\
\mathrm{~cm}^{2}\end{array}$ & $\varepsilon / \%$ & $\begin{array}{c}\text { Error }\left(95 \% \mathrm{Cl}^{\mathrm{a}}\right) \\
\Delta \varepsilon / \% 0\end{array}$ \\
\hline 180.6 & 1.3709 & 1.3674 & -2.6 & 5 & 1.3871 & 11.8 & 5 & 1.3553 & -11.4 & 5 \\
\hline 181.6 & 1.3866 & 1.3496 & -26.7 & 6 & 1.3980 & 8.2 & 6 & 1.3717 & -10.8 & 6 \\
\hline 182.6 & 1.3603 & 1.3362 & -17.7 & 6 & 1.3657 & 4 & 6 & 1.3307 & -21.8 & 6 \\
\hline 183.6 & 1.3576 & 1.3202 & -27.5 & 5 & 1.3558 & -1.3 & 5 & 1.3315 & -19.2 & 5 \\
\hline 184.6 & 1.3419 & 1.3152 & -19.9 & 6 & 1.3479 & 4.5 & 6 & 1.3091 & -24.4 & 6 \\
\hline 185.6 & 1.2936 & 1.2540 & -30.6 & 4 & 1.2822 & -8.8 & 4 & 1.2538 & -30.8 & 4 \\
\hline 186.6 & 1.2680 & 1.2398 & -22.2 & 6 & 1.2729 & 3.9 & 6 & 1.2408 & -21.4 & 6 \\
\hline 187.6 & 1.2050 & 1.1726 & -26.9 & 5 & 1.1949 & -8.4 & 5 & 1.1656 & -32.7 & 5 \\
\hline 188.6 & 1.1524 & 1.1166 & -31.1 & 5 & 1.1508 & -1.4 & 5 & 1.1216 & -26.7 & 5 \\
\hline 189.7 & 1.0963 & 1.0612 & -32 & 4 & 1.0861 & -9.3 & 4 & 1.0551 & -37.6 & 4 \\
\hline 190.7 & 1.0126 & 0.9806 & -31.6 & 6 & 1.0056 & -6.9 & 6 & 0.9756 & -36.6 & 6 \\
\hline 191.7 & 0.9615 & 0.9186 & -44.6 & 5 & 0.9440 & -18.2 & 5 & 0.9130 & -50.5 & 5 \\
\hline 192.7 & 0.8768 & 0.8453 & -35.9 & 5 & 0.8666 & -11.6 & 5 & 0.8369 & -45.5 & 5 \\
\hline 193.7 & 0.8049 & 0.7667 & -47.4 & 6 & 0.7927 & -15.2 & 6 & 0.7638 & -51 & 6 \\
\hline 194.7 & 0.7265 & 0.6985 & -38.6 & 4 & 0.7189 & -10.5 & 4 & 0.6906 & -49.5 & 4 \\
\hline 195.7 & 0.6595 & 0.6302 & -44.5 & 6 & 0.6469 & -19.1 & 6 & 0.6202 & -59.6 & 6 \\
\hline 196.7 & 0.5907 & 0.5624 & -48 & 10 & 0.5823 & -14.3 & 10 & 0.5561 & -58.6 & 10 \\
\hline 196.9 & 0.5799 & 0.5562 & -40.9 & 3 & 0.5703 & -16.7 & 3 & 0.5473 & -56.3 & 3 \\
\hline 197.9 & 0.5124 & 0.4911 & -41.6 & 3 & 0.5059 & -12.8 & 3 & 0.4822 & -58.9 & 3 \\
\hline 198.9 & 0.4548 & 0.4339 & -45.9 & 2 & 0.4463 & -18.6 & 2 & 0.4262 & -62.9 & 2 \\
\hline 199.9 & 0.3993 & 0.3809 & -46.1 & 2 & 0.3914 & -19.7 & 2 & 0.3726 & -66.9 & 2 \\
\hline 200.9 & 0.3462 & 0.3282 & -51.9 & 3 & 0.3386 & -21.9 & 3 & 0.3212 & -72 & 3 \\
\hline 201.9 & 0.2977 & 0.2820 & -52.8 & 3 & 0.2908 & -23.1 & 3 & 0.2749 & -76.5 & 3 \\
\hline 202.9 & 0.2552 & 0.2409 & -56.1 & 3 & 0.2496 & -22.1 & 3 & 0.2346 & -81 & 3 \\
\hline 203.9 & 0.2187 & 0.2056 & -60 & 3 & 0.2133 & -24.8 & 3 & 0.1997 & -87 & 3 \\
\hline 204.9 & 0.1855 & 0.1741 & -61.1 & 3 & 0.1801 & -29 & 3 & 0.1688 & -90.1 & 3 \\
\hline 205.8 & 0.1560 & 0.1450 & -70.4 & 3 & 0.1512 & -31.1 & 3 & 0.1407 & -98.2 & 3 \\
\hline 206.8 & 0.1302 & 0.1211 & -69.6 & 3 & 0.1255 & -35.5 & 3 & 0.1169 & -102.1 & 3 \\
\hline 207.8 & 0.1085 & 0.1004 & -74.7 & 5 & 0.1048 & -34 & 5 & 0.0971 & -104.8 & 5 \\
\hline 208.8 & 0.0906 & 0.0834 & -78.8 & 4 & 0.0873 & -36.1 & 4 & 0.0805 & -110.7 & 4 \\
\hline 209.8 & 0.0746 & 0.0686 & -79.7 & 5 & 0.0720 & -35.1 & 5 & 0.0660 & -114.8 & 5 \\
\hline 210.8 & 0.0613 & 0.0560 & -86.3 & 4 & 0.0588 & -40 & 4 & 0.0539 & -119.9 & 4 \\
\hline 211.8 & 0.0500 & 0.0456 & -87.5 & 5 & 0.0479 & -40.4 & 5 & 0.0437 & -125.1 & 5 \\
\hline 212.8 & 0.0409 & 0.0370 & -96.2 & 8 & 0.0392 & -42.3 & 8 & 0.0356 & -130.2 & 8 \\
\hline 213.8 & 0.0334 & 0.0302 & -97.3 & 11 & 0.0318 & -47.9 & 11 & 0.0290 & -131.5 & 11 \\
\hline 214.8 & 0.0272 & 0.0244 & -101.6 & 11 & 0.0260 & -43.6 & 11 & 0.0234 & -137.3 & 11 \\
\hline 215.8 & 0.0219 & 0.0194 & -112.2 & 12 & 0.0209 & -44.4 & 12 & 0.0188 & -141.5 & 12 \\
\hline 216.8 & 0.0176 & 0.0157 & -107.9 & 18 & 0.0165 & -61.7 & 18 & 0.0147 & -165.3 & 18 \\
\hline 217.8 & 0.0142 & 0.0126 & -113.1 & 17 & 0.0133 & -64 & 17 & 0.0120 & -153.4 & 17 \\
\hline
\end{tabular}

a $95 \%$ confidence intervals.

\subsubsection{Pressure}

The relative cross sections are based on measurements of both the isotopically rare sample and natural abundance nitrous oxide with approximately equal pressures (for the Lund measurements (A) ca. $40 \mathrm{hPa}$ and for the Copenhagen measurements (B) ca. $95 \mathrm{hPa}$ ). This approach minimizes detrimental effects from non-linear or otherwise inaccurate pres- sure gauges and contributions from pressure dependent effects on the absorption cross-section. The pressure of a given gas was measured using a calibrated high-precision capacitance pressure gauge with a nominal accuracy of $0.15 \%$.

For wavelengths above $196.8 \mathrm{~nm}$ no pressure dependence of cross sections for pressures up to $95 \mathrm{hPa}$ was observed. Estimated relative pressure error: $<1 \%$. 
Table 3. Cross sections and fractionation constants at $233 \mathrm{~K}$.

\begin{tabular}{|c|c|c|c|c|c|c|c|c|c|c|}
\hline \multicolumn{2}{|c|}{${ }^{14} \mathrm{~N}^{14} \mathrm{NO}$} & \multicolumn{3}{|c|}{${ }^{14} \mathrm{~N}^{15} \mathrm{NO}$} & \multicolumn{3}{|c|}{${ }^{15} \mathrm{~N}^{14} \mathrm{NO}$} & \multicolumn{3}{|c|}{${ }^{15} \mathrm{~N}^{15} \mathrm{NO}$} \\
\hline $\begin{array}{l}\text { central } \\
\lambda / \mathrm{nm}\end{array}$ & $\begin{array}{c}\sigma / 10^{-19} \\
\mathrm{~cm}^{2}\end{array}$ & $\begin{array}{c}\sigma / 10^{-19} \\
\mathrm{~cm}^{2}\end{array}$ & $\varepsilon / \%$ & $\begin{array}{c}\text { Error }\left(95 \% \mathrm{CI}^{\mathrm{a}}\right) \text { : } \\
\Delta \varepsilon / \% o\end{array}$ & $\begin{array}{c}\sigma / 10^{-19} \\
\mathrm{~cm}^{2}\end{array}$ & $\varepsilon / \%$ & $\begin{array}{c}\text { Error }\left(95 \% \mathrm{CI}^{\mathrm{a}}\right) \text { : } \\
\Delta \varepsilon / \% 0\end{array}$ & $\begin{array}{c}\sigma / 10^{-19} \\
\mathrm{~cm}^{2}\end{array}$ & $\varepsilon / \%$ & $\begin{array}{c}\text { Error }\left(95 \% \mathrm{CI}^{\mathrm{a}}\right) \\
\Delta \varepsilon / \% \circ\end{array}$ \\
\hline 180.6 & 1.3206 & 1.3121 & -6.4 & 7 & 1.3364 & 12 & 7 & 1.2956 & -18.9 & 7 \\
\hline 182.6 & 1.3075 & 1.2806 & -20.6 & 5 & 1.3154 & 6 & 5 & 1.2752 & -24.7 & 5 \\
\hline 184.6 & 1.2685 & 1.2382 & -23.9 & 4 & 1.2781 & 7.6 & 4 & 1.2330 & -28 & 4 \\
\hline 186.6 & 1.1849 & 1.1563 & -24.1 & 5 & 1.1966 & 9.9 & 5 & 1.1550 & -25.2 & 5 \\
\hline 188.6 & 1.0683 & 1.0331 & -32.9 & 5 & 1.0689 & 0.6 & 5 & 1.0306 & -35.3 & 5 \\
\hline 190.7 & 0.9263 & 0.8942 & -34.6 & 5 & 0.9235 & -3 & 5 & 0.8853 & -44.3 & 5 \\
\hline 192.7 & 0.7864 & 0.7574 & -36.8 & 4 & 0.7836 & -3.6 & 4 & 0.7446 & -53.1 & 4 \\
\hline 194.7 & 0.6394 & 0.6128 & -41.6 & 5 & 0.6357 & -5.8 & 5 & 0.6063 & -51.7 & 5 \\
\hline 196.7 & 0.5100 & 0.4833 & -52.5 & 5 & 0.5022 & -15.3 & 5 & 0.4751 & -68.4 & 5 \\
\hline 196.9 & 0.5000 & 0.4738 & -52.4 & 2 & 0.4894 & -21.1 & 2 & 0.4659 & -68.2 & 2 \\
\hline 197.9 & 0.4375 & 0.4144 & -52.6 & 3 & 0.4289 & -19.5 & 3 & 0.4058 & -72.4 & 3 \\
\hline 198.9 & 0.3841 & 0.3614 & -59 & 3 & 0.3742 & -25.6 & 3 & 0.3541 & -78 & 3 \\
\hline 199.9 & 0.3330 & 0.3130 & -60.1 & 2 & 0.3246 & -25.3 & 2 & 0.3051 & -83.8 & 2 \\
\hline 200.9 & 0.2856 & 0.2668 & -65.7 & 3 & 0.2773 & -29 & 3 & 0.2602 & -88.8 & 3 \\
\hline 201.9 & 0.2424 & 0.2259 & -68 & 3 & 0.2352 & -29.6 & 3 & 0.2193 & -95.2 & 3 \\
\hline 202.9 & 0.2052 & 0.1901 & -73.5 & 3 & 0.1985 & -32.7 & 3 & 0.1846 & -100.2 & 3 \\
\hline 203.9 & 0.1733 & 0.1599 & -77 & 3 & 0.1672 & -34.9 & 3 & 0.1551 & -104.8 & 3 \\
\hline 204.9 & 0.1451 & 0.1332 & -82.2 & 3 & 0.1397 & -37.4 & 3 & 0.1287 & -113.2 & 3 \\
\hline 205.8 & 0.1199 & 0.1096 & -86.1 & 4 & 0.1153 & -38.7 & 4 & 0.1058 & -117.2 & 4 \\
\hline 206.8 & 0.0986 & 0.0896 & -91.4 & 4 & 0.0946 & -40 & 4 & 0.0862 & -125.1 & 4 \\
\hline 207.8 & 0.0807 & 0.0727 & -98.2 & 5 & 0.0774 & -40.7 & 5 & 0.0700 & -132.5 & 5 \\
\hline 208.8 & 0.0665 & 0.0597 & -103.1 & 6 & 0.0634 & -46.5 & 6 & 0.0575 & -134.8 & 6 \\
\hline 209.8 & 0.0540 & 0.0482 & -106.4 & 7 & 0.0515 & -46.5 & 7 & 0.0464 & -140.8 & 7 \\
\hline 210.8 & 0.0435 & 0.0385 & -114.7 & 7 & 0.0413 & -50.5 & 7 & 0.0370 & -149.1 & 7 \\
\hline 211.8 & 0.0349 & 0.0308 & -116.7 & 7 & 0.0328 & -58.8 & 7 & 0.0297 & -149.5 & 7 \\
\hline 212.8 & 0.0282 & 0.0246 & -127.1 & 12 & 0.0263 & -68.7 & 12 & 0.0236 & -163.1 & 12 \\
\hline 213.8 & 0.0228 & 0.0198 & -129.5 & 9 & 0.0214 & -62 & 9 & 0.0188 & -176.2 & 9 \\
\hline 214.8 & 0.0182 & 0.0157 & -138.7 & 12 & 0.0171 & -63 & 12 & 0.0149 & -183 & 12 \\
\hline 215.8 & 0.0144 & 0.0122 & -155.3 & 15 & 0.0135 & -60.2 & 15 & 0.0119 & -174.4 & 15 \\
\hline 216.8 & 0.0115 & 0.0095 & -169.3 & 25 & 0.0106 & -74.7 & 25 & 0.0092 & -198.3 & 25 \\
\hline 217.8 & 0.0091 & 0.0076 & -168 & 24 & 0.0082 & -103.7 & 24 & 0.0072 & -209.4 & 24 \\
\hline
\end{tabular}

a $95 \%$ confidence intervals.

\subsubsection{Purity of gas}

The purity of the gas samples is crucial for the accuracy of the quoted fractionation values. The purity of the isotopically rare gas samples was analysed before and after the experiments using FTIR spectroscopy: After the experiments the only detectable non- $\mathrm{N}_{2} \mathrm{O}$ impurities were $\mathrm{CO}_{2}$ and water at mixing ratios of $<0.5 \mathrm{mmol} / \mathrm{mol}$ and $<1 \mathrm{mmol} / \mathrm{mol}$, respectively. For the Copenhagen experiments the reservoir gas was kept at $\mathrm{T}<170 \mathrm{~K}$ during filling of the spectrometer cell, thus the water vapor content was essentially zero. The natural abundance $\mathrm{N}_{2} \mathrm{O}$ sample was analysed using FTIR spectroscopy; no infrared active compounds were present above the detection limit; we estimate the chemical purity to be $>99.9 \%$ (the manufacturer's specification is only $99 \%$ chemical purity). The total estimated error due to impurities of the gas is: $<1.5 \%$ (Lund) and $<1 \%$ (Copenhagen).

\subsubsection{Noise and drift}

The instrumental noise is made up of random fluctuations of light source intensity, detector sensitivity and changing amplification in the data acquisition path in addition to photon counting noise. Problems with long-term drift were minimized by the double beam design; after proper alignment only a minimal drift due to changing beam position of the synchrotron radiation in Lund was encountered. The magnitude of noise was estimated from comparison of consecutive absorbance measurements of the evacuated sample cell. The deviations in calculated cross sections between individual measurements reflected on average the estimated errors due to noise; this makes us confident that no significant additional sources of random error are present. 


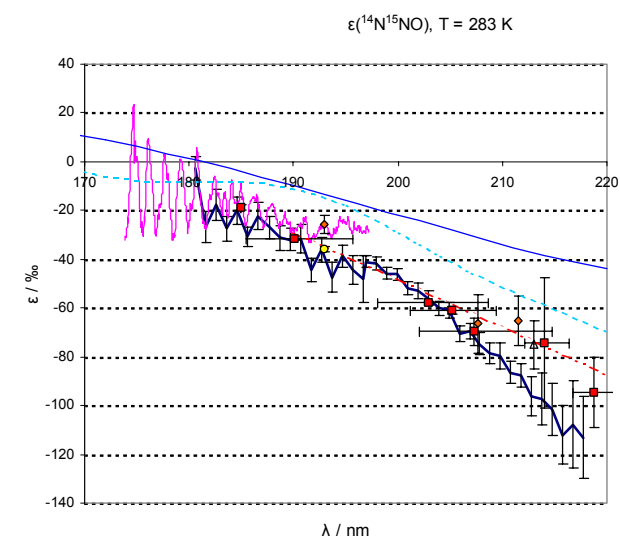

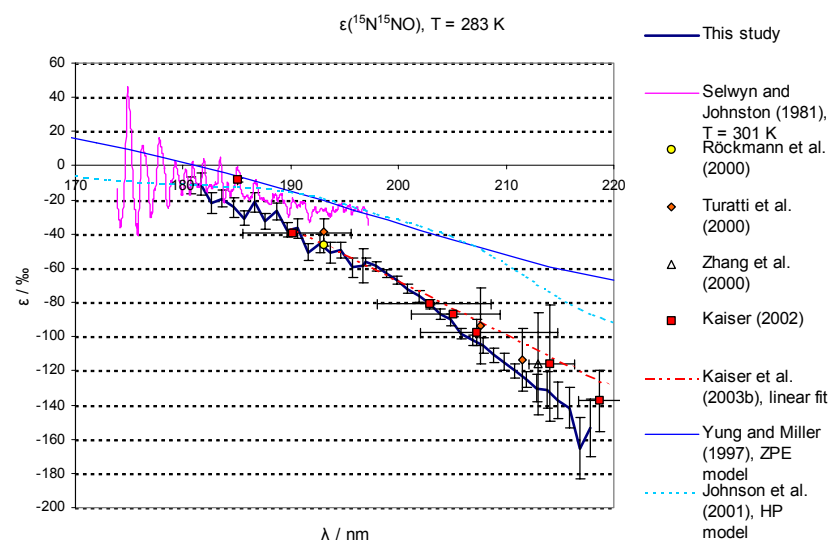

Fig. 3c. Measured fractionation constant $(\varepsilon)$ for ${ }^{15} \mathrm{~N}^{15} \mathrm{NO}$ at $283 \mathrm{~K}$, compared with: previous experiments at room temperature $(298 \mathrm{~K}$ or $301 \mathrm{~K}$ ) temperature and results from model calculations (HP and ZPE models) for $\mathrm{T}=283 \mathrm{~K}$. The data from Röckmann et al. (2000), Turatti et al. (2000), Zhang et al. (2000), Kaiser (2002, 2003b) represent the sum of $\varepsilon\left({ }^{14} \mathrm{~N}^{15} \mathrm{NO}\right)$ and $\varepsilon\left({ }^{15} \mathrm{~N}^{14} \mathrm{NO}\right)$. Y error bars indicate $95 \%$ confidence intervals (this study) and $2 * \sigma$ for the previous studies. X error bars indicate $25 \%$ and $75 \%$ photolysis quartiles for the broadband experiments.
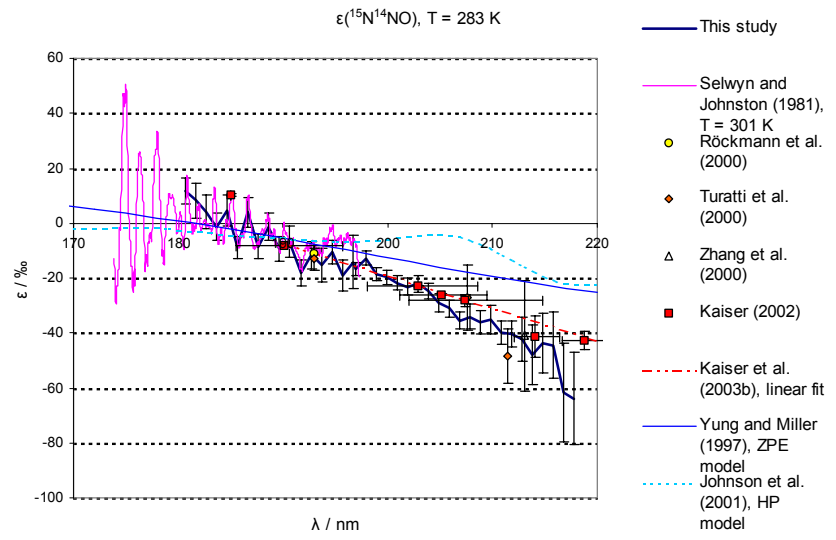

Fig. 3b. Measured fractionation constant $(\varepsilon)$ for ${ }^{15} \mathrm{~N}^{14} \mathrm{NO}$ at $283 \mathrm{~K}$, compared with: previous experiments at room temperature $(298 \mathrm{~K}$ or $301 \mathrm{~K}$ ) and results from model calculations (HP and ZPE models) for $\mathrm{T}=283 \mathrm{~K}$. Y error bars indicate $95 \%$ confidence intervals (this study) and $2 \sigma$ for the previous studies. $\mathrm{X}$ error bars indicate $25 \%$ and $75 \%$ photolysis quartiles for the broadband experiments.

\subsubsection{Temperature}

For all sets of experiments the spectra of natural abundance nitrous oxide measured at the start and end of the corresponding measurement session showed no significant change in cross sections that could be attributed to temperature drift.

\subsubsection{Total uncertainty of fractionation constants}

The total error estimate constitutes the sum of random error (95\% confidence intervals) and an estimated 1\%o (Copenhagen) or $1.5 \%$ (Lund) systematic contribution due to possible impurities in the samples. Pressure, temperature, noise and drift contributions to the error were regarded as being of random nature.

\subsection{Instrumental bandwidth}

The monochromator slit widths in the Lund experiments were $400 \mu \mathrm{m}$ which resulted in an instrumental bandwidth of ca. $0.7 \mathrm{~nm}$. The step size during the scan was $2 \mathrm{~nm}(\mathrm{~T}=233 \mathrm{~K})$ and $1 \mathrm{~nm}(\mathrm{~T}=283 \mathrm{~K})$ - larger than the instrumental bandwidth. This was a mistake: To obtain valid average values for the cross section over the complete spectral range, the instrumental bandwidth should be larger than the step size. The high resolution UV spectrum of nitrous oxide by Yoshino et al. (1984) shows that there is little vibrational fine structure for $\lambda<185 \mathrm{~nm}$. The features measured in our spectra are therefore representative of the spectra which could be obtained with a smaller step size. It can thus be concluded that the potential error due to inconsistent bandwidths and step sizes is limited.

For the Copenhagen experiments $(\lambda>196.8 \mathrm{~nm})$ the instrumental bandwidth was $1.1 \mathrm{~nm}$ and the step size $1 \mathrm{~nm}$.

\subsection{Comparison with other data}

Figures 3 and 4 compare the fractionation constants found in this study with the existing data from single wavelength photolysis experiments, a linear fit on the basis of all available broadband and "single wavelength" photolysis experiments, and results from theoretical studies. A lot of experimental information is available for ${ }^{14} \mathrm{~N}^{15} \mathrm{NO}$ and ${ }^{15} \mathrm{~N}^{14} \mathrm{NO}$ at room temperature: single wavelength experiments in the 


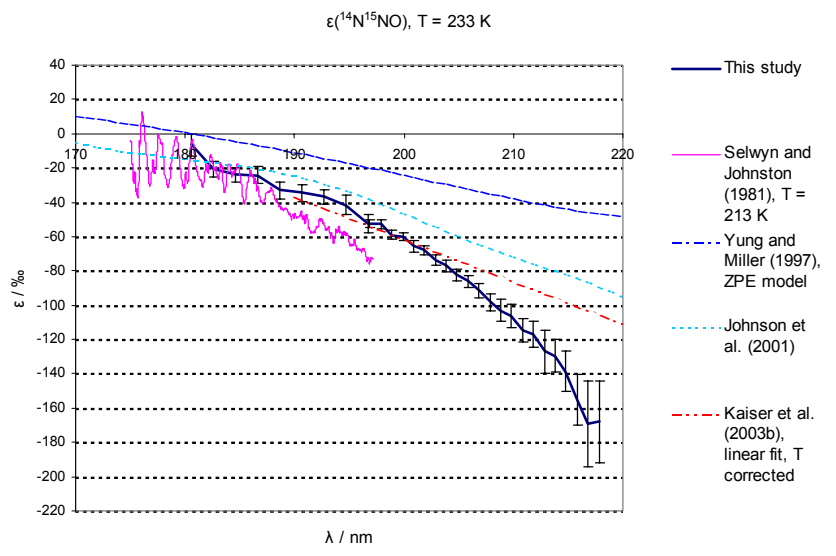

Fig. 4a. Measured fractionation constant $(\varepsilon)$ for ${ }^{14} \mathrm{~N}^{15} \mathrm{NO}$ at $233 \mathrm{~K}$, compared with: Temperature shifted (see Eq. 6) linear fit on basis of photolysis experiments (Kaiser et al., 2003c), HP model results (Johnson et al., 2001) and ZPE model results (Yung and Miller, 1997). Error bars indicate $95 \%$ confidence intervals.

range from 185 to $213 \mathrm{~nm}$ (Kaiser et al., 2002b, 2003c; Rahn et al., 1998; Röckmann et al., 2000, 2001; Toyoda et al., 2001a; Turatti et al., 2000; Umemoto, 1999; Zhang et al., 2000), broadband photolysis experiments (Kaiser et al., 2003c; Röckmann et al., 2001) as well as spectroscopic data from $173 \mathrm{~nm}$ to $197 \mathrm{~nm}$ (Selwyn and Johnston, 1981). For the low temperatures the only existing wavelength resolved experimental data are those from Selwyn and Johnston (1981) from $173 \mathrm{~nm}$ to $197 \mathrm{~nm}$; however a temperature dependence study based on broadband photolysis exists (Kaiser et al., 2002b). For ${ }^{15} \mathrm{~N}^{15} \mathrm{NO}$ the only existing data are those from Selwyn and Johnston and one broadband photolysis study (Kaiser et al., 2003a).

The standard error for the linear fit (Kaiser et al., 2003a) is not shown in Figs. 3 to 5 because it is very small (error $(\mathrm{d} \varepsilon / \mathrm{d} \lambda)=0.02$ to $0.25 \% / \mathrm{nm}$, error $\left(\varepsilon_{200 \mathrm{~nm}}\right)=0.1 \%$ o). This error estimate relies on the validity of the underlying assumption that $\varepsilon$ can be represented by a linear function of $\lambda$.

The magnitude of error on the $\varepsilon$ data from the previous spectroscopic study by Selwyn and Johnston (1981) is not well known, but apparently quite substantial: The authors write: 'at low energies the isotope shift and the random experimental error are about equal'.

Most of the single wavelength photolysis experiments were carried out at mixing ratios of $\geq 4 \mathrm{mmol} / \mathrm{mol}$ (Zhang et al., 2000): ca. $10 \mathrm{mmol} / \mathrm{mol}$, (Turatti et al., 2000): ca. $7 \mathrm{mmol} / \mathrm{mol}$, (Röckmann et al., 2000): ca. $4 \mathrm{mmol} / \mathrm{mol}$ ); for a mixing ratio of $4 \mathrm{mmol} / \mathrm{mol}$, Kaiser et al. (2002b) found a significantly non-linear relationship between $\varepsilon \ln (\mathrm{f})$ and $\ln (1+\Delta \delta)$ at mixing ratios of $4 \mathrm{mmol} / \mathrm{mol}$ (probably due to reaction between $\mathrm{O}\left({ }^{1} \mathrm{D}\right)$ and $\mathrm{N}_{2} \mathrm{O}$ ), while mixing ratios of $1 \mathrm{mmol} / \mathrm{mol}$ produced essentially linear results. The published $\varepsilon$ values are based on the assumption of a linear relationship between $\varepsilon \ln (\mathrm{f})$ and $\ln (1+\Delta \delta)$, therefore the values may be (slightly) erroneous.

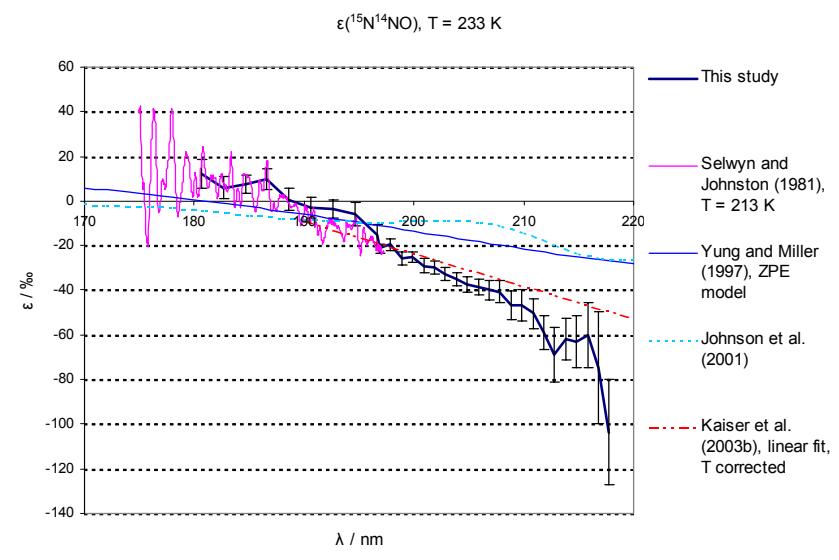

Fig. 4b. Measured fractionation constant $(\varepsilon)$ for ${ }^{15} \mathrm{~N}^{14} \mathrm{NO}$ at $233 \mathrm{~K}$, compared with: Temperature shifted (cf. Eq. 6) linear fit on basis of photolysis experiments (Kaiser et al., 2003c), HP model results (Johnson et al., 2001) and ZPE model results (Yung and Miller, 1997). Error bars indicate $95 \%$ confidence intervals.

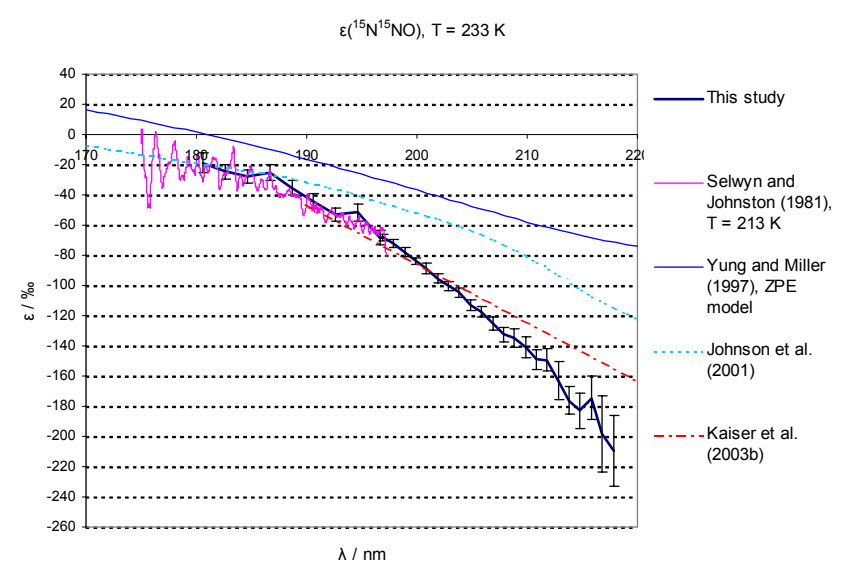

Fig. 4c. Measured fractionation constants for ${ }^{15} \mathrm{~N}^{15} \mathrm{NO}$ at $\mathrm{T}=233 \mathrm{~K}$, compared with model results from the Temperature shifted linear fit (cf. Eq. 6) based on photolysis experiments $\left(\varepsilon\left({ }^{14} \mathrm{~N}^{15} \mathrm{NO}\right)+\varepsilon\left({ }^{15} \mathrm{~N}^{14} \mathrm{NO}\right)(\right.$ Kaiser et al., 2003b), HP model (Johnson et al., 2001) and ZPE model (Yung and Miller, 1997). Error bars indicate $95 \%$ confidence intervals.

\subsubsection{Comparison with previous experiments}

The temperature dependence of $\varepsilon$ is only slight, therefore the data from this study $(\mathrm{T}=283 \mathrm{~K})$ may be directly compared to room temperature measurements.

The agreement with the linear fit from Kaiser et al. (2003a) is largely within the range of error in the wavelength range $190-205 \mathrm{~nm}$ for both ${ }^{15} \mathrm{~N}^{14} \mathrm{NO}$ and ${ }^{14} \mathrm{~N}^{15} \mathrm{NO}$. For ${ }^{15} \mathrm{~N}^{14} \mathrm{NO}$ the disagreement at wavelengths extending to $218 \mathrm{~nm}$ is only slightly larger than the estimated error of this study. For ${ }^{15} \mathrm{~N}^{14} \mathrm{NO}$ the data from this study are in reasonable agreement with the rest of the experimental data (based on single wavelength photolysis and spectroscopy). For ${ }^{14} \mathrm{~N}^{15} \mathrm{NO}$ the 


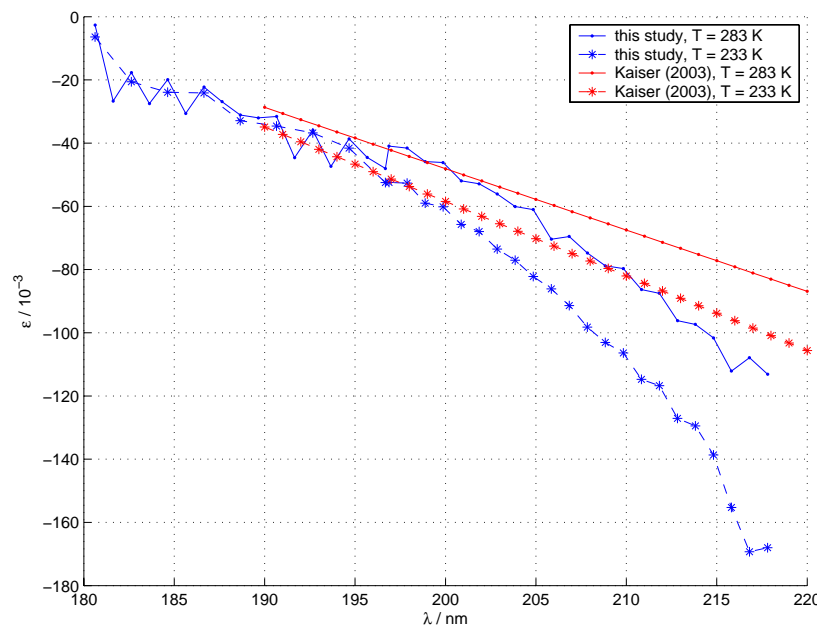

Fig. 5. Temperature dependence of fractionation constant $(\varepsilon)-$ exemplified by ${ }^{14} \mathrm{~N}^{15} \mathrm{NO}$. The reference (Kaiser et al., 2002b) data represent the linear fit of $\varepsilon(\lambda)$ based on combined wavelength dependent room temperature photolysis data (Kaiser et al., 2003c) and broadband photolysis experiments with variable $\mathrm{T}$ (Kaiser et al., 2002b)(cf. Eq. 6).

disagreement with the linear fit grows for $\lambda>205 \mathrm{~nm}$. The data from this study are in good agreement with the single wavelength results for $185 \mathrm{~nm}$ (Kaiser et al., 2003c), $193 \mathrm{~nm}$ (Röckmann et al., 2000) and $207.6 \mathrm{~nm}$ (Turatti et al., 2000); whereas this study is not in agreement with the $193 \mathrm{~nm}$ and $211.5 \mathrm{~nm}$ experiments by Turatti et al. (2000) as well as the $213 \mathrm{~nm}$ experiment by Zhang et al. (2000). The disagreement for $\varepsilon\left({ }^{14} \mathrm{~N}^{15} \mathrm{NO}\right)$ at $\lambda>205 \mathrm{~nm}$ with the existing data is a matter of concern. The disagreement with the linear fit is not so worrying since a closer look at the underlying broadband photolysis results (Kaiser et al., 2002a) reveals that the $95 \%$ confidence intervals of our data overlap with the results from broadband experiments at median wavelengths of ca. 204, 214 and $219 \mathrm{~nm}$ (Kaiser et al., 2003). However considering the better precision and higher wavelength resolution of the present data-set, it seems likely that the $\varepsilon(\lambda)$ has some negative curvature and the linear fit applied by Kaiser et al. (2003c) is most probably not appropriate. This is also in line with the qualitative results from most recent theoretical models, comprising the time-dependent (Johnson et al., 2001; Nanbu and Johnson, 2004) and the semi-empirical 'reflection principle' approaches (Blake et al., 2003; Morgan et al., 2004) - the present findings point to a negative curvature of the function representing $\varepsilon(\lambda)$. The agreement with the previous spectroscopic study (Selwyn and Johnston, 1981) is quite good for all species and temperatures at $\lambda<187 \mathrm{~nm}$. The disagreement at longer wavelengths is probably due to the insufficient accuracy of the old data.

\subsubsection{Comparison with models}

The model results from the HP and ZPE models are in quantitative disagreement with this study. For $283 \mathrm{~K}$ both the HP and ZPE model underestimate the magnitude of isotopic fractionation roughly by a factor of two (around $200 \mathrm{~nm}$ ); at $233 \mathrm{~K}$ the HP model is in better agreement with the measured values in the case of ${ }^{14} \mathrm{~N}^{15} \mathrm{NO}$ and ${ }^{15} \mathrm{~N}^{15} \mathrm{NO}$ (a factor of 1.3 difference for ${ }^{14} \mathrm{~N}^{15} \mathrm{NO}$ and 1.5 for ${ }^{15} \mathrm{~N}^{15} \mathrm{NO}$ ). The ZPE model clearly is a very crude model - only one mass dependent term (the vibrational zero point energy in the electronic ground state) in the complex function representing the photodissociation cross section is considered. As shown in Johnson et al. (2001) a whole suite of mass dependent effects are of importance for the photodissociation cross sections. The disagreement with the HP model results may be explained by the deficiencies of the employed potential energy surface (PES) in the model, which does not incorporate the $\mathrm{N}-\mathrm{N}$ stretching motion.

Morgan et al. (2004) have developed a semi-empirical model for the isotope effects. The detailed description of the employed method and formulae were not available at the time of writing - therefore Figs. 3 and 4 do not show a comparison with these model results. A rough comparison shows that their model is in agreement with the new ${ }^{15} \mathrm{~N}^{14} \mathrm{NO} 283 \mathrm{~K}$ data presented here. Both the ${ }^{14} \mathrm{~N}^{15} \mathrm{NO}$ and ${ }^{15} \mathrm{~N}^{15} \mathrm{NO}$ predictions are shifted towards higher fractionation constants by 15-20\%o compared with the experiments. This leads to an erroneous fractionation factor at the absorption peak wavelength and may be related to the lack of some types of dynamic behaviour in their model as discussed in Sect. 5 .

\section{Modelling}

One way of evaluating these data is to use them in the prediction of stratospheric abundances of the isotopically rare species of nitrous oxide in a global atmospheric model and then compare these predictions with field studies. Twodimensional (Kaiser et al., 2001; Kaiser, 2002; Miller and Yung, 2000; Morgan et al., 2004; Yung and Miller, 1997) and three-dimensional (McLinden et al., 2003) models have been used previously to simulate the distribution of the isotopically rare species of $\mathrm{N}_{2} \mathrm{O}$; however, each of these model studies relied on theoretical values for the cross section fractionation constants. In this work we have the advantage of using detailed laboratory data to model the photolysis.

The simulation of isotopically rare species has been done using the University of California at Irvine (UCI) three dimensional chemistry-transport model (CTM) (McLinden et al., 2000, 2003; Olsen et al., 2001). The source of meteorological fields is the GISS II general circulation model (GCM) (Rind et al., 1988) run at a resolution of $7.8^{\circ}$ latitude $\times 10^{\circ}$ longitude $\times 23$ layers with the top three GCM layers combined into a single CTM layer. This model is able to simulate 
Table 4. Overview of previous studies of $\mathrm{N}_{2} \mathrm{O}$ fractionation constants used as comparison in Figs. 3 and 4.

\begin{tabular}{lllll}
\hline Author(s) & year & method & wavelength/nm & temperature(s)/K \\
\hline Selwyn and Johnston & 1981 & VUV spectroscopy & $173-197$ & 213 and 301 \\
Turatti et al. & 2000 & laser photolysis, FTIR detection & $193,211.5,207.6$ & 298 \\
Röckmann et al. & 2000 & laser photolysis, IRMS detection & 193 & 298 \\
Zhang et al. & 2000 & laser photolysis, FTIR detection & 212.8 & 298 \\
Kaiser et al. & $2003 \mathrm{~b}$ & photolysis with Hg(Ar) lamp, IRMS detection & 185 & 301 \\
Kaiser et al. & $2003 \mathrm{~b}$ & linear fit on basis of broadband and single wavelength photolysis & $190-220$ & room temperature \\
Yung and Miller & 1997 & zero point energy (ZPE) model & all & all \\
Johnson et al. & 2001 & ab initio Hermite propagator (HP) model & all & all \\
\hline
\end{tabular}

realistic $\mathrm{N}_{2} \mathrm{O}$ distributions with a lifetime of about 115 years (Olsen et al., 2001). It has been used previously to model isotopologues of ${ }^{14} \mathrm{~N}^{14} \mathrm{~N}^{16} \mathrm{O}$ by treating each as an independent tracer (McLinden et al., 2003).

In the CTM, chemical loss is implemented using a precalculated loss frequency $\left(\mathrm{J}+\mathrm{k}\left[\mathrm{O}\left({ }^{1} \mathrm{D}\right)\right]\right.$, see Eqs. 1-3) table for each $\mathrm{N}_{2} \mathrm{O}$ isotopologue. Each table is calculated in a photochemical box model (McLinden et al., 2000) as a function of latitude, altitude, and time of year and is based on climatological atmospheres and standard chemical rate data and cross sections (Sander et al., 2000). Photolysis rates (J) for the isotopically rare species $\left({ }^{14} \mathrm{~N}^{15} \mathrm{NO},{ }^{15} \mathrm{~N}^{14} \mathrm{NO}\right.$, and $\left.{ }^{15} \mathrm{~N}^{15} \mathrm{NO}\right)$ are calculated using the standard ${ }^{14} \mathrm{~N}^{14} \mathrm{NO}$ absorption cross sections modified by the cross section fractionation constants in Tables 2 and 3, analogous to the procedure in (McLinden et al., 2003). Loss of the isotopically rare species through the reactions with $\mathrm{O}\left({ }^{1} \mathrm{D}\right)$ is modelled using reaction rate coefficients for ${ }^{14} \mathrm{~N}^{14} \mathrm{NO}$ (Sander et al., 2000) modified by a constant fractionation constant as measured by Kaiser et al. (2002a). To simulate the distributions in the CTM, each of the isotopic species is run to an annually repeating steady state using an arbitrary lower boundary condition of $310 \mathrm{nmol} / \mathrm{mol}$. The isotopic composition of ${ }^{14} \mathrm{~N}^{15} \mathrm{NO},{ }^{15} \mathrm{~N}^{14} \mathrm{NO}$, and ${ }^{15} \mathrm{~N}^{15} \mathrm{NO}$ relative to the mean tropospheric abundance is easily calculated from their abundances relative to that of ${ }^{14} \mathrm{~N}^{14} \mathrm{NO}$. In a comparison with observations, the modelled delta values must be shifted by the value of the bulk troposphere (in essence, the model troposphere has a delta value of $0 \%$ ). Using atmospheric $\mathrm{N}_{2}$ as a reference material, typical tropospheric $\delta$ values have been found to be $30 \%$ o for ${ }^{14} \mathrm{~N}^{15} \mathrm{~N}^{16} \mathrm{O}$ and $-16 \%$ of ${ }^{15} \mathrm{~N}^{14} \mathrm{~N}^{16} \mathrm{O}$ by Kaiser et al. (2003d) or $16 \%$ of ${ }^{14} \mathrm{~N}^{15} \mathrm{~N}^{16} \mathrm{O}$ and $-2 \%$ o for ${ }^{15} \mathrm{~N}^{14} \mathrm{~N}^{16} \mathrm{O}$ by Yoshida and Toyoda (2000). This discrepancy, likely connected to calibration, is yet to be resolved.

The resultant model delta values are evaluated through a comparison with observed (apparent) stratospheric fractionation constants. These are derived assuming a Rayleigh distillation process (Johnson et al., 2002):

$\ln (1+\delta)=\ln \left(1+\delta_{0}\right)+\varepsilon_{a p p} \ln f$

where $f$ is the ratio of stratospheric to tropospheric
${ }^{14} \mathrm{~N}^{14} \mathrm{~N}^{16} \mathrm{O}$ mixing ratios and $\delta=\mathrm{R} / \mathrm{R}_{0}-1$ is the isotopic composition (or delta value) and denotes the heavy-to-light isotope ratio $(R)$ of a given isotopomer relative to some standard $\left(R_{0}\right)$. Comparisons of model apparent stratospheric fractionation constants $\left(\varepsilon_{\text {app }}\right)$ are made with five in-situ datasets (Park et al. 2004; Rahn and Wahlen, 1997; Röckmann et al., 2001; Toyoda et al., 2001b; Yoshida and Toyoda, 2000) and one remotely sensed dataset (Griffith et al., 2000, personal communication, 2002). Stratospheric fractionation constants $\left(\varepsilon_{a p p}\right)$ were derived by fitting the enrichment data to Eq. (5). Each of these datasets, where necessary, has been re-evaluated so that the fractionation constant has been calculated using Eq. (5), as opposed to commonly used approximations (Kaiser, 2002). Also, separate constants have been derived for the lower stratosphere, LS $(-\ln \mathrm{f}>0.6)$ and middle stratosphere, MS $(-\ln \mathrm{f}<0.6)$. This type of comparison has the advantage over a direct comparison of $\delta$ in that a somewhat arbitrary tropospheric offset does not need to be applied to the model data and the measured $\varepsilon_{a p p}$ will have a higher signal to noise ratio than individual $\delta$ values. A least squares fit for $\varepsilon_{a p p}$ is performed restricting the model values used to the month, latitude and $\left[\mathrm{N}_{2} \mathrm{O}\right]$ range of the observations. The observations used in this comparison are summarised in Table 5.

The model-observation comparisons are presented in Fig. 6. Shown are CTM results based on the photolysis fractionation constants of this work and the Hermite Propagation model (Johnson et al., 2001) as shown in McLinden et al. (2003) but using $\mathrm{O}\left({ }^{1} \mathrm{D}\right)$ fractionation factors from Kaiser et al. (2002a). Also included is a CTM simulation using the linear wavelength and temperature parameterisations of the fractionation constants (Kaiser et al., 2002b, 2003c) which were derived from a collection of experimental data. These individual expressions were combined and the following parameterisation resulted:

$\varepsilon(\lambda, T)=\varepsilon_{0}+a \Delta \lambda+b \Delta T+c \Delta \lambda \Delta T$,

where $\quad \Delta \lambda=\lambda-200 \mathrm{~nm}, \quad \Delta T=T-273.15 \mathrm{~K} \quad$ and $\varepsilon_{0}=-51.5 /-20.3 \%$ o, $\quad a=-2.08 /-1.25 \% / \mathrm{nm}$, $b=0.155 / 0.051 \% / \mathrm{K}$, and $c=6.23 \times 10^{-3} / 3.16 \times 10^{-3} \%$ o $\mathrm{nm}^{-1} \mathrm{~K}^{-1}$ for ${ }^{14} \mathrm{~N}^{15} \mathrm{NO} /{ }^{15} \mathrm{~N}^{14} \mathrm{NO}$ ). Differences between 

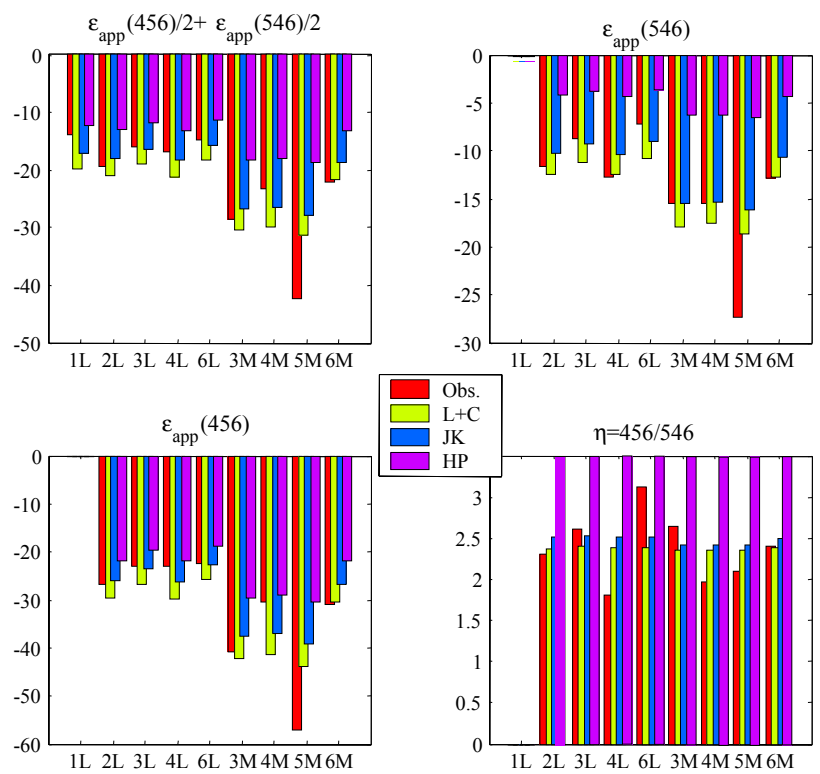

Fig. 6. Comparison of model derived stratospheric fractionation constants $\varepsilon_{a p p}$ (assuming a Rayleigh fractionation process) with observations in \%o. 456 $={ }^{14} \mathrm{~N}^{15} \mathrm{NO}, 546={ }^{15} \mathrm{~N}^{14} \mathrm{NO}$. Bottom right panel compares $\eta$, the $\left[{ }^{14} \mathrm{~N}^{15} \mathrm{NO}\right]:\left[{ }^{15} \mathrm{~N}^{14} \mathrm{NO}\right]$ ratio (a y-axis limit of 3.5 was used to highlight Obs., $\mathrm{L}+\mathrm{C}$, and JK values; $\mathrm{HP}$ values vary from 4.9 to 5.1$)$. Numbers on $\mathrm{x}$-axis indicate the source of the observations as given in Table $5(\mathrm{~L}=$ lower stratosphere, $\mathrm{M}=$ middle stratosphere). $(\mathrm{L}+\mathrm{C}=\mathrm{Lund}+$ Copenhagen data (this work); $\mathrm{JK}=$ parameterisation from Kaiser et al. (2002b, 2003c); HP = Hermite Propagator photolysis model (Johnson et al., 2001) updated with recent $\mathrm{O}\left({ }^{1} \mathrm{D}\right)$ fractionation data (Kaiser et al., 2002a).)

each model and the observations are shown in Fig. 7. The last panel shows the root-mean-square (RMS) differences for each model over all comparisons.

Overall the comparison between the combined Lund/Copenhagen ( $\mathrm{L}+\mathrm{C}$ in Figs. 6 and 7) modelled apparent fractionation constants (Fig. 7) and the observations is very good: root-mean-square (RMS) differences are about 3 to $7 \%$. There does appear to be a slight bias in both ${ }^{14} \mathrm{~N}^{15} \mathrm{NO}$ and ${ }^{15} \mathrm{~N}^{14} \mathrm{NO}$ as the $\mathrm{L}+\mathrm{C}$ values were generally smaller (more negative) than the observations. The comparison with the Kaiser et al. (JK in Figs. 6 and 7) parameterisations is comparable with no obvious bias. Also shown are the HP model results. (Note that the overall impact of the new $\mathrm{O}\left({ }^{1} \mathrm{D}\right)$ fractionation constants on the apparent fractionation is small, $<0.4 \%$.) This model systematically under predicts the apparent fractionation constants, particularly for ${ }^{15} \mathrm{~N}^{14} \mathrm{NO}$ as discussed in McLinden et al. (2003) although we note that for ${ }^{14} \mathrm{~N}^{14} \mathrm{~N}^{18} \mathrm{O}$, not considered in this study, the agreement between the HP model with observations is much better.

Results from the Caltech/JPL two-dimensional model which employs a semi-analytical photolysis model based on the Born-Oppenheimer approximation (Blake et al., 2003;
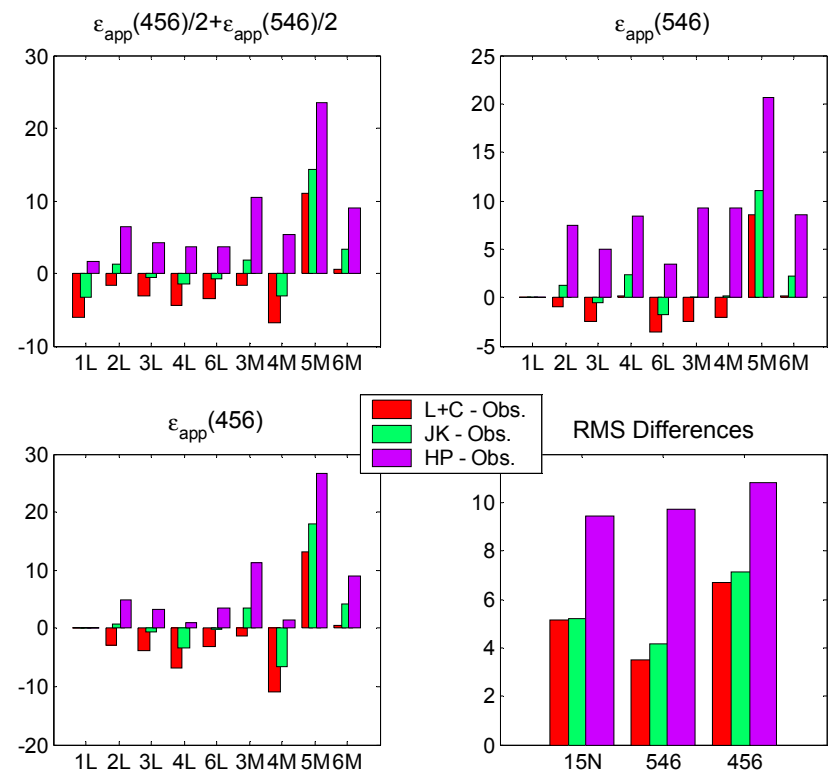

Fig. 7. Differences between model-derived stratospheric fractionation constants $\varepsilon_{a p p}$ (assuming a Rayleigh distillation process) and observations (model-observation) in \%o. The bottom right panel shows the RMS (root mean square) differences over all data sources. Number on $\mathrm{x}$-axis indicate the source of the observations as given in Table $5(\mathrm{~L}=$ lower stratosphere, $\mathrm{M}=$ middle stratosphere $)$. $(\mathrm{L}+\mathrm{C}$ $=$ Lund + Copenhagen data, this work; $\mathrm{JK}=$ parameterisation from Kaiser et al. (2002b, 2003c); HP = Hermite Propagator photolysis model (Johnson et al., 2001) updated with recent $\mathrm{O}\left({ }^{1} \mathrm{D}\right)$ fractionation data.)

Morgan et al., 2004) also appear to be in good agreement with these model results. The good agreement between the $\mathrm{L}+\mathrm{C}$ (and JK) modelled apparent fractionation factors (RMS differences of 3-7\%o) with the observed values strongly suggests there are no unconventional processes involved in fractionating stratospheric $\mathrm{N}_{2} \mathrm{O}$.

The expanded wavelength coverage of these measurements spans the entire range important for atmospheric photolysis and confirms there are no anomalous spectral enrichment features and that the fractionation constant becomes more negative with increasing wavelength, as predicted by theory.

Using the global, annual chemical loss from the model budgets, the annual mean stratospheric loss fractionation constants can be calculated: $-26.1 /-11.1 \%$ o (456/546) for the model using the $\mathrm{L}+\mathrm{C}$ photolysis data and $-22.9 /-9.1 \%$ o for the JK model and $-19.0 /-4.2$ for the HP model.

Compared to an earlier model for the isotopic fractionation due to stratospheric photolysis and chemistry, the experimental fractionation constants predict a smaller annual trend in tropospheric ${ }^{15} \mathrm{~N}$. As derived in McLinden et al. (2003) with the HP model the annual trend in ${ }^{15} \mathrm{~N}$ i.e. $\left(\delta^{15} \mathrm{~N}^{14} \mathrm{NO}+\delta^{15} \mathrm{~N}^{14} \mathrm{NO}\right) / 2$ is ca. $-0.04 \%$ /a; using the JK 
Table 5. Source of data and relevant parameters for model-observation comparisons of stratospheric fractionation constants. Original data has been re-analysed by Kaiser (2002) using Eq. (5) and calculating separate lower stratosphere (LS) and middle stratosphere (MS) apparent fractionation constants with $-\ln \mathrm{f}=0.6$ (about $175 \mathrm{nmol} / \mathrm{mol}$ ) as the border.

\begin{tabular}{lllllll}
\hline$\#$ & Source & Minimum $\mathrm{N}_{2} \mathrm{O}(\mathrm{nmol} / \mathrm{mol})$ & Regions Analysed & Latitude & Time of Year & Original Reference \\
\hline 1 & WB-57 Aircraft & 180 & LS & $33-68^{\circ} \mathrm{N}$ & January-March & Rahn and Wahlen $(1997)^{\mathrm{a}}$ \\
2 & Balloon Sample & 160 & LS & $40^{\circ} \mathrm{N}$ & September & Yoshida and Toyoda $(2000)^{\mathrm{c}}$ \\
3 & Balloon Sample & 10 & LS, MS & $39^{\circ} \mathrm{N}$ & May & Toyoda et al. (2001b) \\
4 & Balloon Sample & 6 & LS, MS & $18-69^{\circ} \mathrm{N}$ & & Röckmann et al. (2001) $^{\mathrm{b}}$ \\
5 & Balloon Occ. & 5 & MS & $34-68^{\circ} \mathrm{N}$ & April-September & Griffith et al. (2000) $^{\mathrm{b}}$ \\
6 & ER-2 Aircraft & 6 & LS, MS & $18-69^{\circ} \mathrm{N}$ & January-September & Park et al. (2004) \\
\hline
\end{tabular}

a $15 \mathrm{~N}$ measured only

${ }^{\mathrm{b}}$ Updated data from Griffith, personal communication (2002)(see McLinden et al., 2003)

${ }^{\mathrm{c}}$ Uses $200 \mathrm{nmol} / \mathrm{mol}(-\ln \mathrm{f} \approx 0.45)$ as the diving line between lower and middle stratosphere

data set the estimated trend is $-0.035 \%$ o a and the estimate using the $\mathrm{L}+\mathrm{C}$ data set gives a trend of $-0.012 \%$ o/a - all of these values with large uncertainties. These may be compared to the recent analysis of Antarctic firn air showing a trend of $-0.041 \%$ ola (Röckmann et al., 2003). The trends have a significant uncertainty. In addition, the budget of McLinden et al. does not employ the most recent results regarding isotope distributions in the various source terms. Nonetheless, we report these results in order to show the effect of the new laboratory data.

\section{Discussion}

Nitrous oxide is an important test system for developing theories of the effect of isotopic substitution on the photolysis cross section of small molecules. It has been known for a long time that electronic excitation spectra change with isotopic substitution, since this will change the position of the rovibrational levels in the ground and excited states. The change in the excited state rovibrational levels is especially important for predissociative spectra and/or systems in which the excited state has a long enough lifetime to result in a structured absorption (Herzberg, 1950). In their 1997 paper, Yung and Miller described a method for estimating the effect of isotopic substitution on the position (energy) of the electronic absorption band in a system with a repulsive excited state. They observed that, due to the Born-Oppenheimer approximation, the excited state potential will be the same for the various isotopically distinct systems, but that slightly different vertical excitation energies will arise from the system's different zero point vibrational energies (ZPE). Thus the absorption spectra of for example a heavy isotopologue would be blue shifted by an amount of energy corresponding to the shift in the ZPE of the heavy isotopologue relative to the isotopically unsubstituted species. This model predicted that heavy isotopic species of nitrous oxide would be photolysed more slowly in the stratospheric UV window than the light parent species ${ }^{14} \mathrm{~N}^{14} \mathrm{NO}$, potentially balancing the isotopic budget and confirming the observation of Kim and Craig (1993).

Subsequent experiments showed isotopic fractionation constants twice as large as predicted by the ZPE theory. Therefore, a study was undertaken using the Hermite Propagator (HP) method to examine factors not included in the ZPE theory, for example the degree of bending excitation in the ground state molecule, and the role of dynamics on the upper state potential energy surface (Johnson et al., 2001). The nitrous oxide molecule has a linear equilibrium geometry. All but about $3 \%$ of the transition intensity in the first UV system of NNO results from a transition ${ }^{1} \Delta \leftarrow{ }^{1} \Sigma^{+}$, that is forbidden since it involves a change in angular momentum quantum number of two, while a photon only carries a single unit of angular momentum. However, the symmetry of the transition changes to $2^{1} \mathrm{~A}^{\prime} \leftarrow \mathrm{X} 1^{1} \mathrm{~A}^{\prime}$ when the molecule bends, resulting in a weakly allowed transition. Even in the lowest bending vibrational state nitrous oxide bends, due to half a quantum of bending vibrational 'zero point' excitation. But, the transition intensity increases with bending vibrational excitation; the ground, first and second excited bending states have an intensity ratio of ca. $1: 3: 6$ (Johnson et al., 2001). Thus the population in the excited bending states makes a significant contribution to the absorption cross-section. The hot bands are especially important to the low energy side of the transition maximum, and result in a relatively large temperature dependence of the absorption cross section in the region of the stratospheric UV window (ca. 200 to $210 \mathrm{~nm}$; Minschwaner et al., 1993). The relative population of the excited bending states is given by the familiar Boltzmann expression:

$$
\frac{n_{v_{i}}}{\sum_{i} n_{v_{i}}}=\frac{e^{-g_{i} \beta \varepsilon_{i}}}{\sum_{j} e^{-g_{j} \beta \varepsilon_{j}}}
$$

where $\beta=1 / \mathrm{kT}, \varepsilon_{i}$ is the energy ( $\left.\varepsilon=\mathrm{h} \mathrm{c} \bar{\nu}\right)$ and $g_{k}$ is the degeneracy of the state in question. 
While nitrous oxide is not the only molecule that has a 'forbidden' transition that becomes allowed due to vibronic interaction (examples include the isoelectronic $\mathrm{CO}_{2}$ and OCS), it is not uncommon to assume that the transition dipole moment does not change very much with the nuclear coordinates of a molecule. This approximation is used for example when Franck-Condon factors are calculated. Brown et al. (1999) have calculated the transition dipole surface for $\mathrm{N}_{2} \mathrm{O}$ and find that it slopes upward from a minimum for a linear geometry. Since isotopically lighter systems will have a slightly larger bending vibrational amplitude than heavy systems (they sit higher in energy in the potential well), they will also have a larger cross section. So, while the ZPE theory predicts a shift along the energy scale, a consideration of the transition dipole surface demands, in addition, a shift in the absorption intensity scale. The ZPE theory predicts that a plot of the fractionation constant versus wavelength will pass through zero at the position of the absorption maximum, about $182 \mathrm{~nm}$ for $\mathrm{N}_{2} \mathrm{O}$. However the plots of the fractionation constants for ${ }^{14} \mathrm{~N}^{15} \mathrm{NO}$ and ${ }^{15} \mathrm{~N}^{15} \mathrm{NO}$ always remain negative, at $283 \mathrm{~K}$ (Figs. 3a and c) and $233 \mathrm{~K}$ (Figs. 4a and c). In contrast, $\varepsilon\left({ }^{15} \mathrm{~N}^{14} \mathrm{NO}\right)$ becomes positive for $\lambda$ shorter than ca. $186 \mathrm{~nm}$ (Fig. 3b) and $188 \mathrm{~nm}$ (Fig. 4b). This dynamical effect, predicted by the HP theory is discussed below.

As discussed, the amplitude of bending vibration is smaller for heavier systems, resulting in a smaller cross section. This effect will increase as the number of bending vibrational quanta increases. In addition, there is an interesting, simultaneous interaction with the Boltzmann population of the excited levels (Eq. 7). On the low energy side of the absorption maximum (i.e. most of the spectral region covered by this work), heavy isotopic species have a lower absorption cross section and thus a negative fractionation constant. Heavy systems also have slower vibrational frequencies, and thus a greater fraction of the heavy systems are in vibrationally excited states at a given temperature. As temperature decreases, there is a larger relative decrease in the population in excited vibrational states (which have a higher intrinsic cross section) for heavy systems than for light. The direction of the Boltzmann/statistical mechanics effect on the cross section is thus opposite to the trend of heavy isotopic species having a smaller cross section than light species for a given number of quanta of bending excitation. Overall, more negative (and larger in magnitude) fractionation constants are observed for heavy isotopic systems as temperature decreases in the hot band region. This may be seen by comparing Figs. $3 \mathrm{a}$ and $4 \mathrm{a}$ for ${ }^{14} \mathrm{~N}^{15} \mathrm{NO}, 3 \mathrm{~b}$ and $4 \mathrm{~b}$ for ${ }^{15} \mathrm{~N}^{14} \mathrm{NO}$ 546 and $3 \mathrm{c}$ and $4 \mathrm{c}$ for ${ }^{15} \mathrm{~N}^{15} \mathrm{NO}$.

The absorption cross section of a given molecule may be calculated using Heller's equation

$\sigma(\omega)=C \omega \int_{-\infty}^{\infty} d t \exp (i E t / \hbar)\left\langle\phi_{0}\left|\exp \left(-\frac{i}{\hbar} H t\right)\right| \phi_{0}\right\rangle$,

(Heller, 1978). This states that the cross section depends on the (Fourier transform with respect to energy of the) correlation function between the original system wavefunction and the time-propagated wavefunction on the excited state potential energy surface $\left(\left\langle\phi_{0}\left|\exp \left(-\frac{i}{\hbar} H t\right)\right| \phi_{0}\right\rangle\right)$. A system which falls apart quickly after photoexcitation will have a smaller absorption cross section than one which has a higher correlation to the original vibrational wavefunction. One of the unique features of the photolysis of nitrous oxide is that the $\mathrm{N}_{2}$ fragment is produced with virtually no vibrational excitation (Hanisco and Kummel, 1993; Neyer et al., 1999a, b). Thus all of the transition energy is ultimately partitioned between electronic energy of the $\mathrm{O}\left({ }^{1} \mathrm{D}\right)$ fragment, rotation of the $\mathrm{N}_{2}$ fragment and translational motion. The amount of rotational excitation is extreme; the rotational distribution of the $\mathrm{N}_{2}$ fragment peaks at over 80 quanta, corresponding to about $1.4 \mathrm{eV}$ of energy. If there were a dynamical effect on the cross section, one would expect it to produce a simultaneous change in the cross section and the partitioning of energy between rotation and translation. The change in zero point energy of ${ }^{14} \mathrm{~N}^{15} \mathrm{~N}^{16} \mathrm{O}$ is $39 \mathrm{~cm}^{-1}$, and for ${ }^{15} \mathrm{~N}^{14} \mathrm{~N}^{16} \mathrm{O}$, $22 \mathrm{~cm}^{-1}$ (frequencies may be found in Johnson et al., 2001). Thus the ZPE theory predicts that the fractionation constant for ${ }^{15} \mathrm{~N}^{14} \mathrm{NO}$ should be about $22 / 39=56 \%$ that of ${ }^{14} \mathrm{~N}^{15} \mathrm{NO}$. Inspection of Figs. $3 \mathrm{~b}$ and $4 \mathrm{~b}$ and analysis of the data in Tables 2 and 3 shows that instead of being greater than half, the fractionation constant of ${ }^{15} \mathrm{~N}^{14} \mathrm{NO}$ is less than half of that of ${ }^{14} \mathrm{~N}^{15} \mathrm{NO}$ (less than $46 \%$, to be precise) for wavelengths shorter than $210 \mathrm{~nm}$, at 233 and $283 \mathrm{~K}$. This means that the absorption cross-section of ${ }^{15} \mathrm{~N}^{14} \mathrm{NO}$ is anomalously high (or that of ${ }^{14} \mathrm{~N}^{15} \mathrm{NO}$ is anomalously low), relative to ${ }^{14} \mathrm{~N}_{2} \mathrm{O}$. Moreover, the absorption cross section of ${ }^{14} \mathrm{~N}^{15} \mathrm{NO}$ is always less than that of ${ }^{14} \mathrm{~N}^{14} \mathrm{NO}$ (negative fractionation constants) at all wavelengths reported in this study, whereas the absorption cross section of ${ }^{15} \mathrm{~N}^{14} \mathrm{NO}$ becomes larger than that of ${ }^{14} \mathrm{~N}^{14} \mathrm{NO}$ already at $189 \mathrm{~nm}(233 \mathrm{~K})$. It is difficult to explain the experimental results using a theory based only on the ground state potential energy surface (e.g. Blake et al., 2003; Yung and Miller, 1997), that does not include dynamics in the excited state. One example is provided by the difference in the photodissociation dynamics of the ${ }^{14} \mathrm{~N}^{15} \mathrm{NO}$ and ${ }^{15} \mathrm{~N}^{14} \mathrm{NO}$ isotopomers. For ${ }^{15} \mathrm{~N}^{14} \mathrm{NO}$, the impulse from the broken bond is pushing against the light end of the $\mathrm{N}_{2}$ fragment, and for ${ }^{14} \mathrm{~N}^{15} \mathrm{NO}$, against the heavy end. An additional dynamic effect is the influence of the spatial extent of the initial bending vibrational wavefunction on the rotational distribution of the $\mathrm{N}_{2}$ fragments. The full dynamics on the three dimensional potential energy surfaces are discussed in the recent work by Nanbu and Johnson (Nanbu and Johnson, 2004). The anomalously large cross section of ${ }^{15} \mathrm{~N}^{14} \mathrm{NO}$ is a dynamical effect that first appeared in the HP model calculations (Johnson et al., 2001), as shown in Fig. 3b and 4b, albeit in a slightly exaggerated form. The clearly different pattern of enrichment for ${ }^{14} \mathrm{~N}^{15} \mathrm{NO}$ and ${ }^{15} \mathrm{~N}^{14} \mathrm{NO}$ is an isotope effect that is independent of molecular mass, but arises solely from the mass distribution within the $\mathrm{N}_{2} \mathrm{O}$ molecule. 


\section{Conclusions}

Wavelength dependent fractionation constants for ${ }^{14} \mathrm{~N}^{15} \mathrm{NO}$, ${ }^{15} \mathrm{~N}^{14} \mathrm{NO}$ and ${ }^{15} \mathrm{~N}^{15} \mathrm{NO}$ were obtained for the wavelength range $181-218 \mathrm{~nm}$ at 233 and $283 \mathrm{~K}$ on basis of UV spectroscopy. The first comprehensive low temperature laboratory dataset on photodissociative isotopic fractionation of nitrous oxide is now available. The new data were used as input to a three dimensional general chemistry-transport model and the modelled stratospheric enrichment in isotopically heavy nitrous oxide was compared to stratospheric measurements showing a very good agreement. The standard model for atmospheric chemistry thus seems to be completely in line with experimental data; no unconventional sources of stratospheric nitrous oxide are needed to explain the observed stratospheric isotope distribution of ${ }^{15} \mathrm{~N}$ in $\mathrm{N}_{2} \mathrm{O}$.

The distribution of ${ }^{15} \mathrm{~N}$ in atmospheric nitrous oxide is not statistical, but a function of the vagaries of this trace gas' biological sources and the linked photochemical/transport sink. Much work remains in the area of understanding these processes, especially in the area of emission sources.

Acknowledgements. Thanks to:

- C. Brenninkmeijer and J. Crowley at the Max Planck Institute for Chemistry, Mainz, Germany for providing gas samples of ${ }^{14} \mathrm{~N}^{15} \mathrm{NO},{ }^{15} \mathrm{~N}^{14} \mathrm{NO}$ and ${ }^{15} \mathrm{~N}_{2} \mathrm{O}$ and the temperature controlled gas cell

- the staff at MAX-lab for extensive on-site support

- G. Somesfalean from the Physics Department of Lund University for providing us with a lock-in amplifier

- For financial support: The Danish Natural Science Research Council, The Nordic Academy for Advanced Study (NorFA) and the Access to Research Infrastructure Programme of the EU

- S. Betak for transportation of equipment

- F. Nicolaisen and K. Feilberg for providing us with pressure gauges and help with analysing FTIR spectra

- I. Trabjerg for the PMT housing and base

- A. von Hessberg for valuable discussions regarding the double beam design

Edited by: D. Lowe

\section{References}

Blake, G. A., Liang, M.-C., Morgan, C. G., and Yung, Y. L.: A Born-Oppenheimer photolysis model of $\mathrm{N}_{2} \mathrm{O}$ fractionation, Geophys. Res. Lett., 30(12), 1656, doi:10.1029/2003GL016932, 2003.

Brown, A., Jimeno, P., and Balint-Kurti, G. G.: Photodissociation of $\mathrm{N}_{2} \mathrm{O}, \mathrm{Ab}$ initio potential energy surfaces for the low lying electronic states $\mathrm{X}^{1} \mathrm{~A}^{\prime}, 2{ }^{1} \mathrm{~A}^{\prime}$, and $1^{1} \mathrm{~A}^{\prime \prime}$, J. Phys. Chem. A, 103, $11089-11095,1999$.

Crutzen, P. J.: The influence of nitrogen oxides on the atmospheric ozone content, Q. J. R. Meteorol. Soc., 96, 320-325, 1970.
DeMore, W. B., Sander, S. P., Golden, D. M., Hampson, R. F., Kurylo, M. J., Howard, C. J., Ravishankara, A. R., Kolb, C. E., and Molina, M. J.: Chemical kinetics and photochemical data for use in stratospheric modelling, JPL Publication, 97-4, 163-164, 1997.

Feilberg, K. L., Sellevåg, S. R., Nielsen, C. J., Griffith, D. W. T., and Johnson, M. S.: $\mathrm{CO}+\mathrm{OH}->\mathrm{CO}_{2}+\mathrm{H}$ : The relative reaction rate of five $\mathrm{CO}$ isotopologues, Phys. Chem. Chem. Phys., 4(19), 4687-4693, 2002.

Griffith, D. W. T., Toon, G. C., Sen, B., Balvier, J.-F., and Toth, R. A.: Vertical profiles of nitrous oxide isotopomer fractionation measured in the stratosphere, Geophys. Res. Lett., 27, 24852488, 2000.

Hanisco, T. F. and Kummel, A. C.: State-resolved photodissociation of $\mathrm{N}_{2} \mathrm{O}$, J. Phys. Chem., 97(28), 7242-7246, 1993.

Heller, E. J.: Quantum corrections to classical photo-dissociation models, J. Chem. Phys., 68(5), 2066-2075, 1978.

Herzberg, G.: Spectra of Diatomic Molecules, D. van Nostrand Company Inc., 1950.

Houghton, J. T., Ding, Y., Griggs, D. J., Noguer, M., van der Linden, P. J., Dai, X., Maskell, K., and Johnson, C. A.: Climate Change 2001: The Scientfic Basis, Cambridge University Press, 2001.

Johnson, M. S., Billing, G. D., Gruodis, A., and Janssen, M. H. M.: Photolysis of nitrous oxide isotopomers studied by timedependent Hermite propagation, J. Phys. Chem. A, 105, 86728680, 2001.

Johnson, M. S., Feilberg, K. L., von Hessberg, P., and Nielsen, O. J.: Isotopic processes in atmospheric chemistry, Chem. Soc. Rev., 31(6), 313-323, 2002.

Johnston, J. C., Cliff, S. S., and Thiemens, M. H.: Measurement of multioxygen isotopic (delta ${ }^{18} \mathrm{O}$ and delta ${ }^{17} \mathrm{O}$ ) fractionation factors in the stratospheric sink reactions of nitrous oxide, J. Geophys. Res., 100(D8), 16801-16804, 1995.

Kaiser, J.: Stable isotope investigations of atmospheric nitrous oxide, Ph.D. Thesis, Johannes Gutenberg Universität, Mainz, 2002.

Kaiser, J., Röckmann, T., Brühl, C., and Brenninkmeijer, C. A. M.: Isotopic enrichment in stratospheric $\mathrm{N}_{2} \mathrm{O}$ : 2-D model results linked to laboratory measurements of $\mathrm{N}_{2} \mathrm{O}$ photochemistry, Geophys. Res. Abs., 3, 5784, 2001.

Kaiser, J., Brenninkmeijer, C. A. M., and Röckmann, T.: Intramolecular ${ }^{15} \mathrm{~N}$ and ${ }^{18} \mathrm{O}$ fractionation in the reaction of $\mathrm{N}_{2} \mathrm{O}$ with $\mathrm{O}\left({ }^{1} \mathrm{D}\right)$ and its implications for the stratospheric $\mathrm{N}_{2} \mathrm{O}$ isotope signature, J. Geophys. Res., 107(D14), 4214, 2002a.

Kaiser, J., Röckmann, T., and Brenninkmeijer, C. A. M.: Temperature dependence of isotope fractionation in $\mathrm{N}_{2} \mathrm{O}$ photolysis, Phys. Chem. Chem. Phys., 4(18), 4420-4430, 2002b.

Kaiser, J., Röckmann, T., and Brenninkmeijer, C. A. M.: Assessment of ${ }^{15} \mathrm{~N}^{15} \mathrm{~N}^{16} \mathrm{O}$ as a tracer of stratospheric processes, Geophys. Res. Lett., 30(2), Art. no. 1046, doi:10.1029/2002GL016253, 2003a.

Kaiser, J., Röckmann, T., and Brenninkmeijer, C. A. M.: Complete and accurate mass spectrometric isotope analysis of tropospheric nitrous oxide, J. Geophys. Res., 108(D15), 4476, 2003b.

Kaiser, J., Röckmann, T., Brenninkmeijer, C. A. M., and Crutzen, P. J.: Wavelength dependence of isotope fractionation in $\mathrm{N}_{2} \mathrm{O}$ photolysis, Atmos. Chem. Phys., 3, 303-313, $2003 \mathrm{c}$.

Kaiser, J., Park, S., Boering, K. A., Brenninkmeijer, C. A. M., Hilkert, A., and Röckmann, T.: Mass-spectrometric method for the absolute calibration of the intramolecular nitrogen isotope distri- 
bution in nitrous oxide, Anal. Bioanal. Chem., 378(2), 256-269, 2003d.

Kim, K.-R. and Craig, H.: Nitrogen-15 and oxygen-18 characteristics of nitrous oxide: A global perspective, Science, 262, 18551857, 1993.

McElroy, M. B. and Jones, D. B. A.: Evidence for an additional source of atmospheric $\mathrm{N}_{2} \mathrm{O}$, Global Biogeochemical Cycles, 10(1), 651-659, 1996.

McLinden, C. A., Olsen, S., Hannegan, B., Wild, O., Prather, M. J., and Sundet, J.: Stratospheric ozone in 3-D models: A simple chemistry and the cross-tropopause flux, J. Geophys. Res., 105, 14 653-14 665, 2000.

McLinden, C. A., Prather, M. J., and Johnson, M. S.: Global modeling of the isotopic analogues of $\mathrm{N}_{2} \mathrm{O}$ : Stratospheric distributions, budgets, and the ${ }^{17} \mathrm{O}-{ }^{18} \mathrm{O}$ mass-independent anomaly, J. Geophys. Res., 108(D8), 4233, 2003.

Merienne, M. F., Coquart, B., and Jenouvrier, A.: Temperature effect on the ultraviolet absorption of $\mathrm{CFCl}_{3}, \mathrm{CFCl}_{2}$ and $\mathrm{N}_{2} \mathrm{O}$, Planet. Space Sci., 38(5), 617-625, 1990.

Miller, C. E. and Yung, Y. L.: Photo-induced isotopic fractionation of stratospheric $\mathrm{N}_{2} \mathrm{O}$, Chemosphere, 2, 255-266, 2000.

Minschwaner, K., Salawitch, R. J., and McElroy, M. B.: Absorption of solar radiation by $\mathrm{O}_{2}-$ implications for $\mathrm{O}_{3}$ and lifetimes of $\mathrm{N}_{2} \mathrm{O}, \mathrm{CFCl}_{3}$, and $\mathrm{CF}_{2} \mathrm{Cl}_{2}$, J. Geophys. Res. A, 98(D6), $10543-$ $10561,1993$.

Morgan, G. C., Allen, M., Liang, M. C., Shia, R. L., Blake, G. A., and Yung, Y. L.: Isotopic fractionation of nitrous oxide in the stratosphere: Comparison between model and observations, J. Geophys. Res., 109(D4), D04305, doi:10.1029/2003JD003402, 2004.

Nanbu, S. and Johnson, M. S.: Analysis of the ultraviolet absorption cross sections of six nitrous oxide isotopomers using $3 \mathrm{D}$ wavepacket propagation, J. Phys. Chem. A, in press, 2004.

Neyer, D. W., Heck, A. J. R., and Chandler, D. W.: Photodissociation of $\mathrm{N}_{2} \mathrm{O}$ : J-dependent anisotropy revealed in $\mathrm{N}_{2}$ photofragment images, J. Chem. Phys., 110(2), 3411-3417, 1999a.

Neyer, D. W., Heck, A. J. R., and Chandler, D. W.: Speeddependent alignment and angular distributions of $\left.\mathrm{O}^{1}{ }^{1} \mathrm{D}_{2}\right)$ from the ultraviolet photodissociation of $\mathrm{N}_{2} \mathrm{O}$, J. Phys. Chem. A, 103(49), 10388-10397, 1999b.

Olsen, S., McLinden, C. A., and Prather, M. J.: Stratospheric $\mathrm{N}_{2} \mathrm{O}-$ $\mathrm{NO}_{\mathrm{y}}$ system: Testing uncertainties in a 3-D framework, J. Geophys. Res., 106(28), 28 771-28 784, 2001.

Park, S., Atlas, E. L., and Boering, K. A.: Measurements of $\mathrm{N}_{2} \mathrm{O}$ isotopologues in the stratosphere: Influence of transport on the apparent enrichment factors and the isotopologue fluxes to the troposphere, J. Geophys. Res., 109, D01305, 2004.

Prasad, S. S.: Potential atmospheric sources and sinks of nitrous oxide 2. Possibilities from excited $\mathrm{O}_{2}$, "embryonic" $\mathrm{O}_{3}$, and optically pumped excited $\mathrm{O}_{3}$, J. Geophys. Res., 102(D17), $21527-$ 21 536, 1997.

Rahn, T. and Wahlen, M.: Stable isotope enrichment in stratospheric nitrous oxide, Science, 278, 1776-1778, 1997.

Rahn, T., Zhang, H., Wahlen, M., and Blake, G. A.: Stable isotope fractionation during ultraviolet photolysis of $\mathrm{N}_{2} \mathrm{O}$, Geophys. Res. Lett., 25(24), 4489-4492, 1998.

Rind, D., Suozzo, R., Balachandran, N. K., Lacis, A., and Russell, G.: The GISS global climate/middle atmosphere model, I. Model structure and climatology, J. Atmos. Sci., 45, 329-370, 1988.
Rothman, L. S., Barbe, A., Benner, D. C., et al.: The HITRAN molecular spectroscopic database: edition of 2000 including updates through 2001, J. Quant. Spectrosc. Radiat. Transfer, 82(14), 5-44, 2003.

Röckmann, T., Brenninkmeijer, C. A. M., Wollenhaupt, M., Crowley, J. N., and Crutzen, P. J.: Measurement of the isotopic fractionation of ${ }^{15} \mathrm{~N}^{14} \mathrm{~N}^{16} \mathrm{O},{ }^{14} \mathrm{~N}^{15} \mathrm{~N}^{16} \mathrm{O}$ and ${ }^{14} \mathrm{~N}^{14} \mathrm{~N}^{18} \mathrm{O}$ in the UV photolysis of nitrous oxide, Geophys. Res. Lett., 27(9), 13991402, 2000.

Röckmann, T., Kaiser, J., Brenninkmeijer, C. A. M., Crowley, J. N., Borchers, R., Brand, W. A., and Crutzen, P. J.: Isotopic enrichment of nitrous oxide $\left({ }^{15} \mathrm{~N}^{14} \mathrm{NO},{ }^{14} \mathrm{~N}^{15} \mathrm{NO},{ }^{14} \mathrm{~N}^{14} \mathrm{~N}^{18} \mathrm{O}\right)$ in the stratosphere and in the laboratory, J. Geophys. Res., 106(D10), 10 403-10 410, 2001.

Röckmann, T., Kaiser, J., Brenninkmeijer, and C. A. M.: The isotopic fingerprint of the pre-industrial and the anthropogenic $\mathrm{N}_{2} \mathrm{O}$ source, Atmos. Chem. Phys., 3, 315-323, 2003.

Sander, S. P., Friedl, R. R., DeMore, W. B., Golden, D. M., Kurylo, M. J., Hampson, R. F., Huie, R. E., Moortgat, G. K., Ravishankara, A. R., Kolb, C. E. and Molina, M. J.: Chemical kinetics and photochemical data for use in stratospheric modeling, in Evaluation 13, JPL Publication, Pasadena, California, 00-003, 2000.

Selwyn, G. S. and Johnston, H. S.: Ultraviolet absorption spectrum of nitrous oxide as function of temperature and isotopic substitution, J. Chem. Phys., 74(2), 3791-3803, 1981.

Selwyn, G., Podolske, J., and Johnston, H. S.: Nitrous oxide ultraviolet absorption spectrum at stratospheric temperatures, Geophys. Res. Lett., 4(10), 427-430, 1977.

Sorensen, S. L., Olsson, B. J., Huldt, S., Johansson, S.-E., Källne, E., Nilsson, A. E., Hutton, R., Litzén, U., and Svensson, A.: A normal-incidence beam line at the MAX storage ring, Nuclear Instruments and Methods in Physics Research, A297, 296-300, 1990.

Toyoda, S., Yoshida, N., Suzuki, T., Tsuji, K., and Shibuya, K.: Isotopomer fractionation during photolysis of nitrous oxide by ultraviolet light of $206 \mathrm{~nm}$ to $210 \mathrm{~nm}$, International Conference on the Study of Environmental Change using Isotope Techniques, edited by IAEA, International Atomic Energy Agency, Vienna, Austria, 2001a.

Toyoda, S., Yoshida, N., Urabe, T., Aoki, S., Nakazawa, T., Sugawara, S., and Honda, H.: Fractionation of $\mathrm{N}_{2} \mathrm{O}$ isotopomers in the stratosphere, J. Geophys. Res., 106(D7), 7515-7522, $2001 \mathrm{~b}$.

Turatti, F., Griffith, D. W. T., Wilson, S. R., Esler, M. B., Rahn, T., Zhang, H., and Blake, G. A.: Positionally dependent ${ }^{15} \mathrm{~N}$ fractionation factors in the UV photolysis of $\mathrm{N}_{2} \mathrm{O}$ determined by high resolution FTIR spectroscopy, Geophys. Res. Lett., 27(16), 2489-2492, 2000.

Umemoto, H.: ${ }^{14} \mathrm{~N} /{ }^{15} \mathrm{~N}$ isotope effect in the UV photodissociation of $\mathrm{N}_{2} \mathrm{O}$, Chem. Phys. Lett., 314(3-4), 267-272, 1999.

Yoshida, N. and Matsuo, S.: Nitrogen isotope ratio of atmospheric $\mathrm{N}_{2} \mathrm{O}$ as a key to global cycle of $\mathrm{N}_{2} \mathrm{O}$, Geochemical Journal, 17, 231-239, 1983.

Yoshida, N. and Toyoda, S.: Constraining the atmospheric $\mathrm{N}_{2} \mathrm{O}$ budget from intramolecular site preference in $\mathrm{N}_{2} \mathrm{O}$ isotopomers, Nature, 405, 330-334, 2000.

Yoshida, N., Morimoto, H., and Matsuo, S.: UV photolysis and microbial reduction as major sinks of nitrous oxide with emphasis on kinetic nitrogen isotope discrimination, Eos Trans. AGU, 
71(28), 933-934, 1990.

Yoshino, K., Freeman, D. E., and Parkinson, W. H.: High-resolution absorption cross-section measurements of $\mathrm{N}_{2} \mathrm{O}$ at $295 \mathrm{~K}-299 \mathrm{~K}$ in the wavelength region 170-222 nm, Planet. Space Sci., 32(10), 1219-1222, 1984.

Yoshino, K., Esmond, J. R., and Parkinson, W. H.: High-resolution absorption cross section measurements of $\mathrm{NO}_{2}$ in the UV and visible region, Chem. Phys., 221, 169-174, 1997.

Yung, Y. L. and Miller, C. E.: Isotopic fractionation of stratospheric nitrous oxide, Science, 278, 1778-1780, 1997.
Yung, Y. L., Wang, W. C., and Lacis, A. A.: Greenhouse effects due to atmospheric nitrous oxide, Geophys. Res. Lett., 3, 619-621, 1976.

Zhang, H., Wennberg, P. O., Wu, V. H., and Blake, G. A.: Fractionation of ${ }^{14} \mathrm{~N}^{15} \mathrm{~N}^{16} \mathrm{O}$ and ${ }^{15} \mathrm{~N}^{14} \mathrm{~N}^{16} \mathrm{O}$ during photolysis at 213 nm, Geophys. Res. Lett., 27(16), 2481-2484, 2000.

Zipf, E. C. and Prasad, S. S.: Experimental evidence that excited ozone is a source of nitrous oxide, Geophys. Res. Lett., 25(23), 4333-4336, 1998. 